\title{
Bacterial Exopolysaccharides: Insight into Their Role in Plant Abiotic Stress Tolerance
}

\author{
Neeta Bhagat*, Meenu Raghav, Sonali Dubey, and Namita Bedi \\ Amity Institute of Biotechnology, Amity University Uttar Pradesh, Sector 125, Noida 201301, India
}

\begin{abstract}
Various abiotic stressors like drought, salinity, temperature, and heavy metals are major environmental stresses that affect agricultural productivity and crop yields all over the world. Continuous changes in climatic conditions put selective pressure on the microbial ecosystem to produce exopolysaccharides. Apart from soil aggregation, exopolysaccharide (EPS) production also helps in increasing water permeability, nutrient uptake by roots, soil stability, soil fertility, plant biomass, chlorophyll content, root and shoot length, and surface area of leaves while also helping maintain metabolic and physiological activities during drought stress. EPS-producing microbes can impart salt tolerance to plants by binding to sodium ions in the soil and preventing these ions from reaching the stem, thereby decreasing sodium absorption from the soil and increasing nutrient uptake by the roots. Biofilm formation in high-salinity soils increases cell viability, enhances soil fertility, and promotes plant growth and development. The third environmental stressor is presence of heavy metals in the soil due to improper industrial waste disposal practices that are toxic for plants. EPS production by soil bacteria can result in the biomineralization of metal ions, thereby imparting metal stress tolerance to plants. Finally, high temperatures can also affect agricultural productivity by decreasing plant metabolism, seedling growth, and seed germination. The present review discusses the role of exopolysaccharide-producing plant growth-promoting bacteria in modulating plant growth and development in plants and alleviating extreme abiotic stress condition. The review suggests exploring the potential of EPS-producing bacteria for multiple abiotic stress management strategies.
\end{abstract}

Keywords: Exopolysaccharides (EPS), drought, abiotic stress, salinity, metal, biofilm

Received: May 10, 2021 Accepted: June 17, 2021

First published online: June 21, 2021

* Corresponding author Phone: +7042420808 E-mail:nbhagat@amity.edu

pISSN 1017-7825 eISSN 1738-8872

Copyright(C) 2021 by The Korean Society for Microbiology and Biotechnology

\section{Introduction}

Abiotic stresses like drought, salinity, heavy metals, and high or low temperature are major constraints to crop production by being detrimental to the physical, metabolic, and growth development of plants [1]. Plants are often subjected to multiple stresses which are aggravated by climatic changes, use of chemical fertilizers, pesticides and environmental pollution. This situation is more alarming with the increase in world population which is expected to reach around 10 billion by 2050 [2]. There is an urgent need to increase food production by $70 \%$ to meet the demand [2]. It is also imperative to find ways to implement new agricultural strategies to protect crops from these multiple abiotic stressors [3].

Currently, there are several approaches that enhance plant tolerance to abiotic stress. These include waterconserving irrigation strategies, traditional methods of breeding, and genetic engineering of transgenic plants with abiotic stress tolerance [4]. Plant growth-promoting rhizosphere microorganisms are also now being widely used for restoring soil fertility, remediation of chemical pollutants and to sustain plant growth [5]. They are a proven, effective alternative to conventional methods and a promising strategy for mitigating abiotic stresses. The use of plant growth-promoting microorganisms is a simple alternative approach to genetic engineering and breeding methods for crop improvement since these procedures are time-consuming, expensive, and laborious [6]. These microorganisms improve the root and shoot growth, thus enhancing the water and nutrient absorption from soil [7]. Different types of plant metabolites, such as HCN, 2,4-diacetylphloroglucinol (DAPG) [8], antibiotics, e.g., phenazine [9], and volatile compounds [10] help to enhance plant growth [11-13]. Exopolysaccharides, are produced by an array of microorganisms like bacteria, cyanobacteria, microalgae, yeasts, and fungi [14]. These exopolysaccharides impart defense against a wide range of environmental stresses like drought [15], metals [16], salt [17], and temperature [18]. Additionally, EPS facilitate microbe-microbe and microbe-plant interaction, provide antioxidants, store carbon, and supply nutrients to support plant growth [6, 19]. Diverse bacterial species like Pseudomonas aeruginosa, Azotobacter vinelandii, Sphingomonas paucimobilis, Azotobacter, Paenibacillus, Klebsiella, Bacillus, and Pseudomonas spp. produce EPS and play an important role in sustaining plant growth in abiotic stress environments [20]. The root microbiome, specifically rhizospheric microbes produce phytohormones, 1-aminociclopropane-1-carboxylase (ACC) deaminase, and EPS to sustain 
plant growth in drought. Crosstalk between phytohormones such as auxins, ethylene, gibberellins, cytokinins, jasmonic acid and transcription factors play a significant role in this abiotic stress tolerance [21].

Interestingly, the composition and concentration of the EPS that is produced varies in different strains, leading to various structural and functional types of EPS [22].The quantity and components of the EPS produced by bacteria depend on several factors such as type of bacteria, time of cultivation, state of growth, and availability of substrate $[3,23]$. Therefore, the diversity of constituents present in the EPS imparts unique properties such as enhancement of water absorption and holding capacity of bacteria in the soil by means of aggregate formation [24]. Although EPS-producing bacteria are ubiquitously distributed in nature, there is a gap in knowledge with regard to the factors that are involved in the regulation, synthesis and variations in composition of EPS produced by plant growth-promoting bacteria in response to different abiotic stresses.

EPS-producing strains are more efficient in imparting resistance to abiotic stress compared to plant growthpromoting rhizosphere bacteria originated from the non-stress ecosystem [25]. Presence of these EPS strains influences plant growth and thus such bacteria are promising candidate biostimulants for stress management strategies for plant growth and development [25]. In the present review we discuss the role of exopolysaccharideproducing bacteria in combating abiotic stress in plants.

\section{Bacterial EPSs}

EPSs are extracellular polymers of bacterial origin. They are produced in response to environmental signals as an energy exchange mechanism [26]. ESPs are a complex mixture of diverse types of biomolecules forming a 3D structural matrixome containing polysaccharides, sugars, structural proteins, enzymes, amino sugars, nucleic acids, lipids, pyruvates, glycoproteins, lipids, extracellular DNA, and some humic substances [23]. Each of these components vary in physicochemical properties and functions. Acetate esters, pyruvates, formates, and succinates are the common extracellular carbohydrate substituents found in EPS [27]. The EPS backbone contains repeating units of monosaccharides, classified as homopolysaccharides and heteropolysaccharides [28]. Homopolymers are made up of single sugars such as pentoses (arabinose, and xylose), hexoses (glucose, galactose, mannose, allose), desoxyhexoses (rhamnose, fucose), amino sugars (glucosamine and galactosamine), or uronic acids (glucuronic acids and galacturonic acids) linked by strong 1,4- $\beta$ - or 1,3- $\beta$-1 and more flexible 1,2- $\alpha$ - or 1,6- $\alpha$ linkages. Heteropolysaccharides contain two to three different sugar moieties in repeated fashion. The carbohydrates may be linked to proteins (glycoproteins), lipids (glycolipids), acids (e.g., glucuronic acid, galacturonic acid, or mannuronic acid), and/or extracellular DNA. The succinate and pyruvate substituents, uronic acids, and phosphate and sulfate residues, provide anionic charge to the matrix which easily captures many cations like metals, sodium, and potassium [29].

These polysaccharides are responsible for cell adhesion, cell aggregation and water retention while forming a protective barrier and providing nutrient sources. In addition, proteins in the matrix provide binding enzymes (adhesins), electron acceptors and donors, and facilitate the absorption of organic and inorganic material. EPS amino acids serve as carbon and nitrogen sources for bacteria [30]. Nucleic acid also serves as source nutrients and genetic information. Humic substance supports adhesion and provides electron donor and acceptor [31]. In general, bacteria produce two types of EPS:capsular EPS (CPS), which is attached to the cell surface, and released polysaccharides (RPS-EPS), which are released by the bacterial cell into the surroundings. Extracellular enzymes of EPS facilitate nutrient absorption from aqueous medium and help in distribution as EPS changes from soluble to filamentous matrix form [32]. EPS helps in cohesion of bacteria, adhesion of biofilm to the root surface, and enables exchange of metabolic signaling information amongst bacteria to form a stable population with synergistic relationship [33]. There are 4 steps involved in the biosynthesis of EPS: 1) absorption, activation and conversion of monosaccharides into sugar nucleotides in the cytoplasm; 2) assembly of sugar nucleotide repeat units by the sequential addition of each unit on a lipid carrier molecule with the help of glycosyltransferase; 3 ) polymerization of these repeat units that occurs at the periplasmic side of the plasma membrane, and 4) exudation of EPS to the cell surface [32] (Fig. 1). The matrix of EPSs holds an assembly of microbial colonies to form biofilm. Formation of biofilms is regulated by multiple factors including metabolic signaling of quorum sensing [33]. Roots usually release secondary metabolite like phenolics, organic acids, amino acids and phytohormones, and siderophores in the form of root exudates. These exudates serve as chemoattractants for microbes associated with roots by electrostatic interaction and later develop the biofilm [34]. The quorum sensing (QS) system plays an important role in plant-microbe and microbe-microbe interactions in root harboring bacteria which promote plant growth during stress [35]. Strigolactones have been the signal molecules for plant microbe communication facilitating entry of bacteria into the roots of the plant. In bacteria two QS pathways (autoinducer-1 [AI-1] and autoinducer-2 [AI-2]) have been reported in bacteria (Miller, Waters) [35-37]. QS signal molecules, N-acyl homoserine lactones (AHLs), are commonly secreted in gram-negative bacteria, while autoinducer peptides are found in gram-positive bacteria. The AHLs serve as signaling molecules responsible for regulating the microbial population density in biofilm [36, 41]. The bacteria QS system helps bacteria acquire nutrition, ferric ions by siderophores, provides stress tolerance and produces antibiotics to inhibit pathogens [38]. QS signals also enhance root elongation, nodulation, and production of growth promoters like auxin and flavonoids to promote plant growth [38-40].

Microbial EPSs improve the quality and fertility of soil [41]. High-molecular-weight polymers in EPS help soil bacteria attach to the exterior of soil particles and sustain the collected particles. The EPSs adhere to soil surfaces through hydrogen binding, cation bonds, anion adsorption, and van der Waal's forces [42]. By decreasing wetting and swelling, this organic outcome may facilitate the firmness of the soil aggregate aeration, permeation, root penetration, and decrease runoff [42]. EPS helps in microaggregation of soil by forming a organo-mineral sheath 


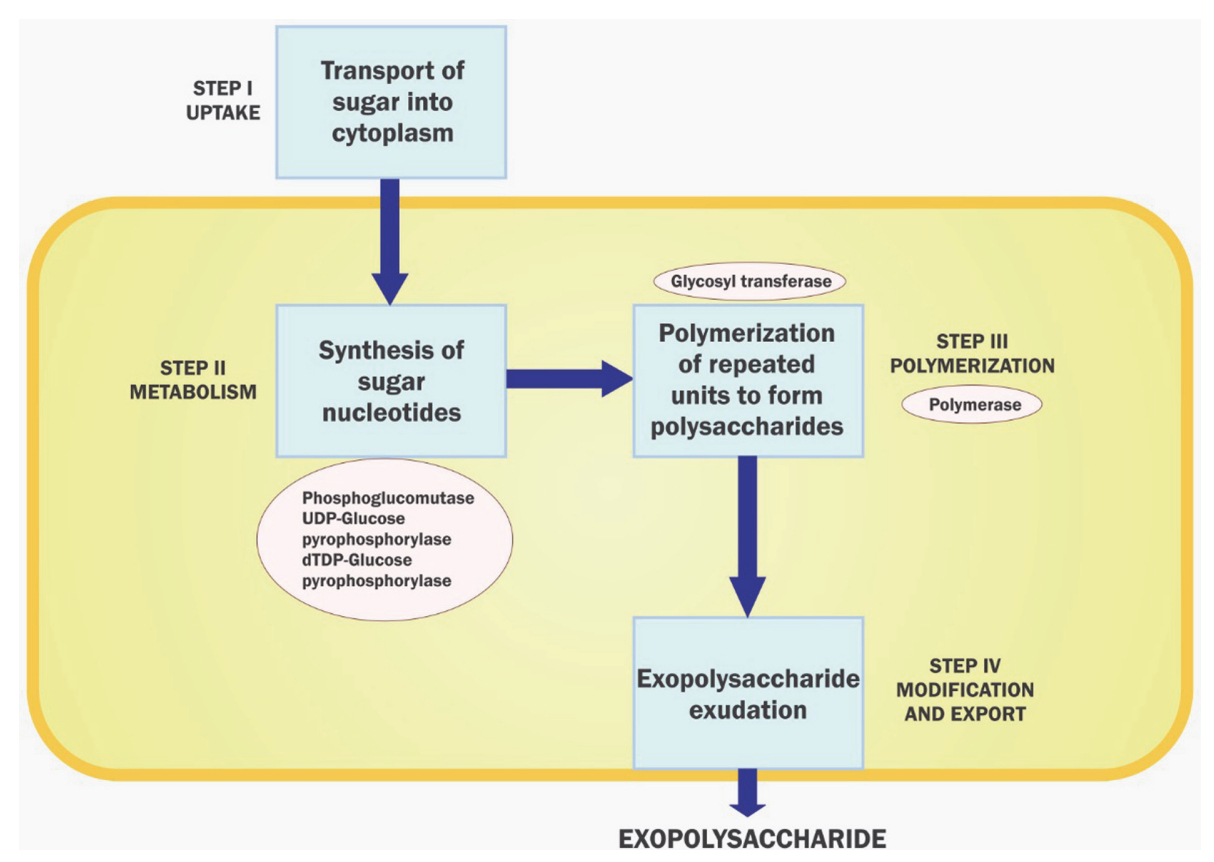

Fig. 1. Steps involved in biosynthesis of bacterial exopolysaccharides.

Table 1. EPS-producing bacterial strains in soil aggregation.

\begin{tabular}{llr}
\hline \multicolumn{1}{c}{ Microorganisms } & \multicolumn{1}{c}{ Roles of EPS } & References \\
\hline Microbacterium arborescens & Cementing of soil particles & {$[55]$} \\
Bacillus sp. & Soil aggregation & {$[88]$} \\
Pseudomonas mendocina & Promote soil fertility and stabilization & {$[51]$} \\
Rhizobium sp. & Soil aggregation & {$[48]$} \\
& Increase in water holding capacity of soil in rhizosphere & {$[52]$} \\
Pseudomonas putida strain GAP-p45 & Soil aggregation increase root adherence stability & \\
& Biofilm formation on surface of root of sunflower seedling & \\
\hline
\end{tabular}

which improves the soil structure and provides stability to soil under stress conditions [41, 43] (Table 1).

Many plant growth-promoting rhizosphere bacteria maintain plant-water relations, ion homeostasis and photosynthetic efficiency in plants under drought and salt stress. Stress alleviation involves a complex signalling network operating as a result of plant-microbe interaction [35]. Thus, EPS as nutrient facilitator and adhesive matrix for attaching microbes to plants plays an important mediator in maintaining plant heath in abiotic stress. A positive correlation exists between abiotic stress and production of EPS by bacterial cells [44] (Fig. 2).

\section{Role of EPS in Mitigation of Drought Stress in Plants}

One of the major agronomic complications that affect crop yields in arid and semi-arid regions all over the world is drought stress [45]. Prolonged periods of drought up to many years and intensely acute environments of drought have the potential to lead to food scarcity in some countries [2, 46]. Drought-inflicted areas are considered high stress environments due to inaccessibility of water and variations in environmental humidity. The development and yield of crops are highly restricted in arid and semi-arid regions that are affected by drought stress and the properties and stability of soils are adversely affected [47]. As a result, it is essential to understand the effects of drought on other environmental phenomena such as soil aggregation in order to learn how plant growth can be enhanced under drought conditions [47].

Arid and semi-arid areas harbor different clusters of microorganisms that aid in the growth of plants in stressed environments by several mechanisms such as ACC, phytohormone regulation, antioxidant production, volatile organic compounds, and EPS production [13, 19]. Various studies have been done to prove the important roles of EPS in inducing survival mechanisms under drought stress $[2,19]$. As EPS is hygroscopic in nature, it helps in maintaining high water content for the survival of microorganisms under drought conditions [6].

As discussed previously, the EPS produced by different bacterial strains improves soil aggregation and increases water permeability and nutrient uptake around the roots, thereby supporting plant growth and protecting plants from drought stress $[7,12]$. EPS produced by Rhizobium KYGT207 strain is rich in glucose (Glc), galactose (Gal), and mannuronic acid (ManA) and increases root-adhering soil (RAS) which facilitates the nutrient and water uptake in Tritium significantly [48]. The capsule of Azospirillum brasilense Sp245 strain was shown to possess complexes of high-molecular-weight components, such as complexes between lipopolysaccharides and proteins, 


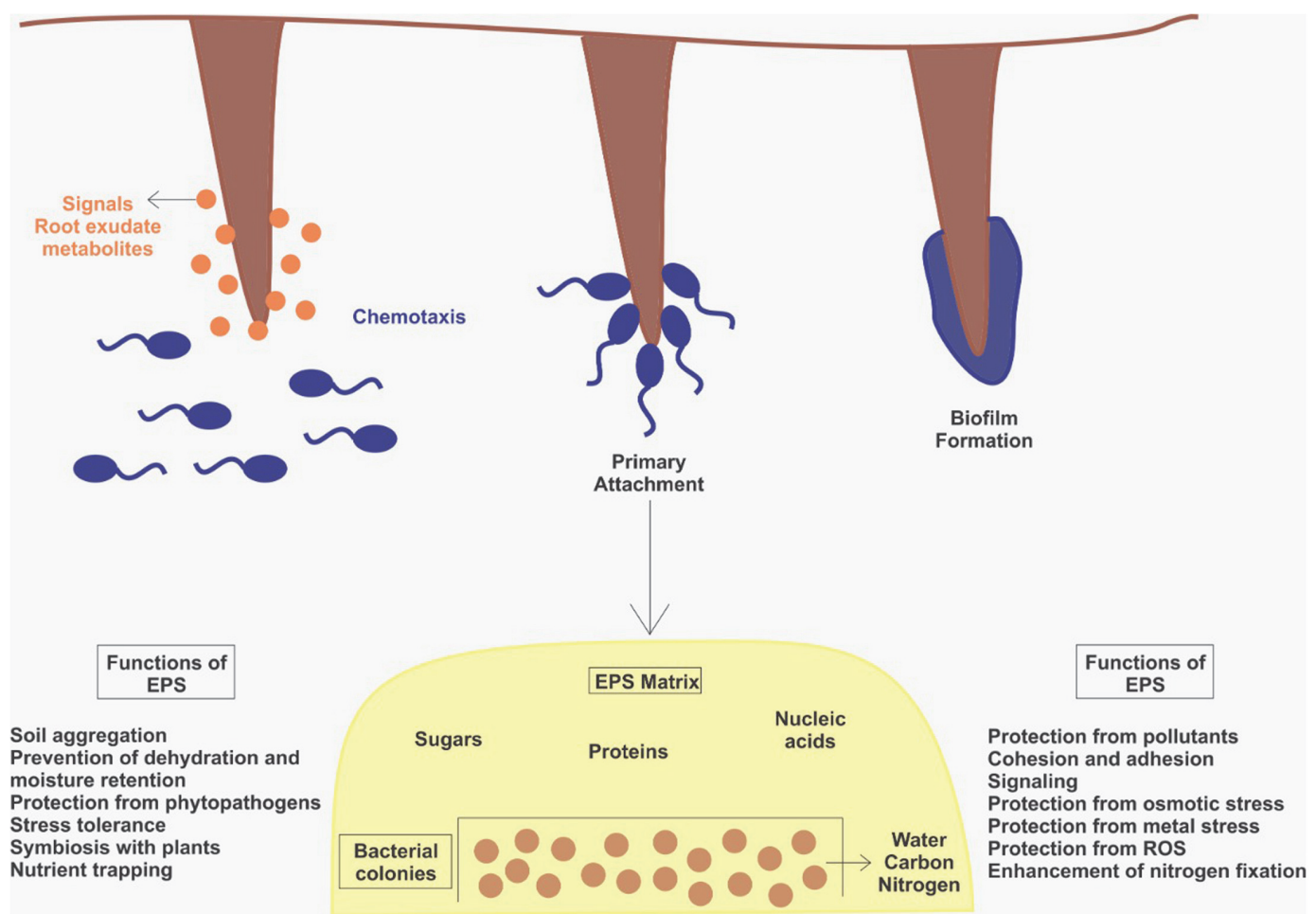

Fig. 2. Roles of EPS microbial exopolysaccharides in mitigation of abiotic stress and plant growth promotion.

and polysaccharides and lipids, which could offer protection under extreme environmental conditions such as desiccation [49]. Even upon decapsulation, cells of the A. brasilense Sp245 strain could survive under drought conditions [49]. Pseudomonas mendocina increased stabilization as well as soil fertility under drought stress [50]. Similarly, the EPS produced by Pseudomonas putida GAP-P45 strain reported to form biofilms on the surface of roots of sunflower seedlings, which promoted soil aggregate formation and enhanced stability of the rhizosphere region $[19,52]$. This strain colonizes the rhizosphere and forms stable soil aggregates, increases plant biomass, and enhances the survival rate and RAS/root tissue (RT) ratio which promotes water and nutrient uptake thereby boosting plant survival under drought [52]. Under water deficit stress, EPS production was increased in different Bacillus species such as B. licheniformis strain HYTAPB18, B. amyloliquefaciens strain HYD-B17, and B. subtilis strain RMPB. Under drought stress HYTAPB18 and RMPB44 contained glucose and HYD-B17 produced raffinose as major sugar in EPS [53]. EPS, being fibrillar by nature, entangles with clay particles and forms microaggregates $(<250 \mu \mathrm{m}$ diameter) and macroaggregates ( $>250 \mu \mathrm{m}$ diameter) by creating an intermediate zone where EPS and clay particles combine and become surrounded with bulk soil $[19,52]$.

When EPS-producing Rhizobium species were used as bioinoculants, they increased soil stability under drought conditions [54]. Similarly, Microbacterium arborescens has been shown to produce different polysaccharides that have the property of cementing soil particles together [55] (Table 1). Increase in levels of total carbohydrates in soils of arid regions is attributed to different types of EPS secreted by microorganisms [12,34]. Maize seedlings that were primed with three different EPS-producing strains - P. aeruginosa Pa2, Proteus penneri Pp1, and Alcaligenes faecalis AF3 - demonstrated improvement in soil moisture, increase in plant biomass, root and shoot length, and surface area of leaves in maize plants under water deficit stress. The plants also showed an increase in their sugar, protein, proline, and relative water content, and a decrease in the activities of their antioxidant enzymes [56, 57]. Similarly, inoculation of wheat plant with EPS-producing Mesorhizobium ciceri CR-30 and CR39, Rhizobium leguminosarum LR-30, and Rhizobium phaseoli MR-2 resulted in an improvement in plant growth and biomass and enhancement of the drought resistance capacity of wheat seedlings [58].

Drought stress increases levels of antioxidative enzymes and reactive oxygen species (ROS) in plants [59]. However, when these plants are treated with EPS-producing bacteria, they show a significant increase in the levels of catalase, ascorbate peroxidase, and glutathione peroxidase. P. mendocina showed the ability to augment catalase activity in lettuce under drought stress [51,60]. Rhizobium species and Serratia species also enhanced drought resistance in lettuce by increasing antioxidant levels under drought stress conditions. Priming with these EPSproducing bacteria is reported to increase levels of antioxidant enzymes in several other plants like barley, wheat, sunflower, maize, and chickpea $[11,61]$.

High proline concentration supports maintenance of high turgor pressure, which is important for maintaining metabolic and physiological activities in plant cells under drought conditions [62]. Also, EPS-producing Plant Growth-Promoting Rhizobacteria (PGPR) such as B. licheniformis B642 and Pseudomonas fluorescens FAP2 strains were found to possess plant growth-promoting (PGP) traits such as production of siderophores, IAA, 
ammonia, and phosphate solubilization. Plants inoculated with these strains showed significant increase in vegetative growth, transpiration rate $(\mathrm{E})$, chlorophyll content, stomatal conductance $\left(\mathrm{g}_{\mathrm{s}}\right)$, internal $\mathrm{CO}_{2}$ concentration (Ci), leaf water potential (LWP), and net photosynthetic rate $\left(\mathrm{P}_{\mathrm{N}}\right)$ as compared to uninoculated plants [62]. Pseudomonas species with EPS-producing ability have been shown to trigger the upregulation of the proline pathway to maintain high concentration of proline under drought stress [63]. Pepper plants treated with EPS-producing B. licheniformis K11 strain showed the presence of six differentially expressed stress proteins and a 1.5 -fold increase in the products of specific genes such as vacuolar $\mathrm{H}^{+}$-ATPase (VA), dehydrin-like protein (Capsicum annuum) Cadhn, cytoplasmic small heat shock protein class I (sHsp), and Capsicum annuum pathogenesis-related protein 10 (CaPR) as compared to untreated plants exposed to drought stress [64]. EPSproducing Planomicrobium chinense and Bacillus cereus showed the ability to improve the sugar and protein content in leaves, and increase the chlorophyll content, chlorophyll fluorescence, and Performance Index (PI) in maize plants growing under rain-fed conditions, thereby increasing their drought tolerance $[58,65]$.

Lu et al. [66] studied the role of the epsC gene in EPS-producing B. amyloliquefaciens FZB42 on drought tolerance mechanisms of Arabidopsis by producing a mutant without eps $C$ gene. Inoculation with mutant strains decreased growth and tolerance of plants in drought stress. The results showed that bacterial strain had a significant effect on drought tolerance and growth of the plants as evidenced by increase in survival rate, weight of fresh and dry shoot, weight of dry root, primary and lateral root length, and lateral root number. Additionally, there was also improvement in proline levels, cellular defense responses, and activities of peroxidase and superoxide dismutase. Inoculation with the FZB42 strain was reported to reduce lipid peroxidation and hydrogen peroxide accumulation in plants. Also, there was an increase in the expression levels of marker genes related to drought tolerance such as ERD1, RD17, LEA14, and RD29A in the leaves of plants inoculated with FZB42. The study also supported that the drought tolerance of FZB42-treated Arabidopsis plants was enhanced not by eps $C$ which determines colonization of bacteria in the roots and induces systemic drought tolerance in Arabidopsis [66]. Plant growth-promoting bacteria isolated from the rhizosphere region of chickpea plant were characterized for the production of EPS, hydrogen cyanide $(\mathrm{HCN})$, indole-3-acetic acid (IAA), and ammonia $\left(\mathrm{NH}_{3}\right)$. It was seen that the protein and sugar content of EPS were $98 \%$ and $96 \%$ in Bacillus megaterium, and $98 \%$ and $95 \%$ in B. thuringiensis and B. subtilis. The uronic acid content was found to be maximum (94\%) in B. megaterium. All these strains were capable of inducing metabolic changes like accumulation of L-arginine, L-isoleucine, proline, Lhistidine, tryptophan, L-asparagine, aspartate, riboflavin, nicotinamide, glycerol, and 3-hydroxy-3-methylglutarate in chickpea leaves to induce drought resistance $[11,60]$. Biofilm formation by the $B$. amyloliquefaciens 54 strain improved drought resistance by increasing the survival rate, root vigor, and relative water content [67]. This ability of the bacteria was shown to have a significant effect on multiple pathways such as decreasing the concentration of malondialdehyde, increasing the concentration and activity of antioxidant enzymes, and increasing the expression of stress-responsive genes like ltpg2, tdi65, and lea, as demonstrated by mutant studies of the strain. Plants that were inoculated with mutants capable of hyper-robust biofilm formation $(\triangle a b r B$ and $\triangle y w c C)$ were found to demonstrate drought resistance as compared to plants that were inoculated with mutants having biofilm formation defects $(\triangle e p s A-O$ and $\triangle \operatorname{tas} A)$ which could not grow in water deficit conditions. Therefore, these studies confirm that the ability to form biofilms helped the B. amyloliquefaciens 54 strain enhance drought tolerance of tomato plant [67].

Indigenous rhizobacteria capable of forming biofilms such as Bacillus species, Pseudomonas species, Brevibacterium species, Pantoea species, and Acinetobacter species have demonstrated several significant plant growth-promoting attributes and induced drought tolerance in wheat plants [12, 62]. Similarly, Arabidopsis thaliana seedlings inoculated with Bacillus tequilensis J12, Bacillus endophyticus J13, P. aeruginosa ZNP1, and $P$. aeruginosa PM389 strains showed the ability to counteract the adverse effects of osmotic stress conditions by improvement in fresh and dry weight and water content of the plant as compared to uninoculated plants exposed to osmotic stress. Among these four strains, the B. endophyticus J13 and P. aeruginosa ZNP1 strains demonstrated increased ability for EPS production when exposed to osmotic stress [68].

Different Rhizobium species such as $R$. strain R1, R. tropici R2, R. cellulosilyticum R3, R. taibaishanense R4, and $E$. meliloti $\mathrm{R} 5$ strains that were isolated from the rhizosphere of Bambara groundnut plants to enhanced seed germination of soybean (PAN $1532 \mathrm{R}$ ) plants when exposed to drought. Genomic studies on these strains have revealed the involvement of auxin, $h t r A$, nodA, exoX, Nif, eptA, and siderophore-producing genes responsible for promotion of plant growth and drought tolerance [69]. Sushilowati et al. [70] identified EPS-producing droughtresistant bacteria such as B. megaterium, B. licheniformis, and Bacillus pumilus that imparted drought-tolerant properties to the soybean plant. High EPS formation by ACC deaminase-producing $P$. fluorescens DR7 could colonize the rhizospheric soil and enhanced RAS/RT ratio, supporting that this probably improved the microenvironment of the soil by holding water in drought environment and promoted growth of foxtail millet (Setaria italica L.) in arid regions [71].

Another study reported that EPS-producing strains like P. fluorescens, Enterobacter hormaechei, and Pseudomonas migulae isolated from soil of foxtail millet (S. italica L.), a drought-tolerant crop, produced EPS in direct relation to the population size of the strain [21]. EPS from P. chlororaphis O6 reduced the wilting in A. thaliana when applied to seedlings while reducing the stomatal opening when applied to leaf of the plant [72]. Polyssaccharide from $M$. arborescens helps to cement soil particles together and stabilizes the soil [55]. This soil aggregation is dependent on the dose of the inoculum as reported by Vardhajula et al., 2014, using Bacillus spp. strains HYD-B17, HYTAPB18 and RMPB44 in drought as well as non-stressed conditions [19, 73]. Incubation period also determines the production of EPS and aggregation of soil [73] (Table 1). Microenvironments created by EPSproducing bacteria in soil in drought helps to concentrate minerals in drought stress and support soil structure 
Table 2. EPS-producing microbial strains in drought tolerance.

\begin{tabular}{|c|c|c|c|}
\hline Microorganisms & Crops & Functions & References \\
\hline Rhizobium sp. strain YAS34 & Sunflower & Increase RAS/RT ratio, dry biomass, and nitrogen uptake & {$[24]$} \\
\hline Pseudomonas mendocina & $\begin{array}{l}\text { Lactuca } \\
\text { sativa } \mathrm{L}\end{array}$ & $\begin{array}{l}\text { Increase in aggregate stability, water soluble, and total } \\
\text { carbohydrates }\end{array}$ & {$[50]$} \\
\hline $\begin{array}{l}\text { Proteus penneri } \\
\text { Pseudomonas aeruginosa } \\
\text { Alcaligenes faccalis }\end{array}$ & Maize & $\begin{array}{l}\text { Improve soil moisture content, leaf area, root length, shoot } \\
\text { length, and plant biomass }\end{array}$ & {$[56]$} \\
\hline $\begin{array}{l}\text { Bacillus sp. } \\
\text { (B. amyloliquefaciens, } \\
\text { B. licheniformis, B. thuringiensis, } \\
\text { B. subtilis, Paenibacillus favisporus) }\end{array}$ & Maize & $\begin{array}{l}\text { Increase plant biomass, relative water content, water } \\
\text { potential of leaf, RAS/RT ratio, and aggregate stability }\end{array}$ & {$[11]$} \\
\hline $\begin{array}{l}\text { Rhizobium leguminosarum } \\
\text { Mesorhizobium ciceri } \\
\text { Rizobium phaseoli }\end{array}$ & Wheat & Improve growth, biomass, and drought tolerance index & {$[58]$} \\
\hline Rhizobium strain KYGT207 & Wheat & Improve soil aggregation & {$[48]$} \\
\hline $\begin{array}{l}\text { Bacillus sp. } \\
\text { (B. licheniformis, B. megaterium, } \\
\text { B. pumilus) }\end{array}$ & Soybean & Plant growth promotion & {$[70]$} \\
\hline Klebsiella sp. IG3 & Wheat & $\begin{array}{l}\text { Improve soil aggregation, root adhering soil, and water } \\
\text { potential around the roots }\end{array}$ & {$[75]$} \\
\hline $\begin{array}{l}\text { P. aeruginosa } \mathrm{PM} 389 \\
\text { P. aeruginosa } \mathrm{ZNP} 1 \\
\text { B.endophyticus } \mathrm{J} 13 \\
\text { B. tequilensis } \mathrm{J} 12\end{array}$ & & $\begin{array}{l}\text { Increase phytohormones/EPS } \\
\text { Enhance fresh weight, dry weight, and plant water content }\end{array}$ & {$[68]$} \\
\hline Pseudomonas chlororaphis $\mathrm{O} 6$ & $\begin{array}{l}\text { Arabidopsi } \\
\text { s thaliana }\end{array}$ & Reduce stomatal opening and wilting & {$[72]$} \\
\hline B. amyloliquefaciens 54 & Tomato & $\begin{array}{l}\text { Increase survival rate, relative water content, and root vigor } \\
\text { Decrease concentration of malondialdehyde } \\
\text { Increase antioxidant enzyme activities } \\
\text { Increase levels of stress-responsive genes (lea, tdi65, and } \\
\text { ltpg2) }\end{array}$ & [96] \\
\hline B. amyloliquefaciens FZB42 & A. thaliana & $\begin{array}{l}\text { Increase survival rate, fresh and dry shoot weights, and } \\
\text { primary root length } \\
\text { Increase expression levels of drought defense-related } \\
\text { marker genes, such as RD } 29 A, R D 17, E R D 1 \text {, and } L E A 14 \\
\text { Increase proline production and activities of superoxide } \\
\text { dismutase and peroxidase }\end{array}$ & {$[66]$} \\
\hline $\begin{array}{l}\text { Pseudomonas fluorescens DR7 } \\
\text { P. fluorescens DR } 11 \\
\text { Pseudomonas migulae DR35 } \\
\text { Enterobacter hormaechei DR16 }\end{array}$ & $\begin{array}{l}\text { Foxtail } \\
\text { millet }\end{array}$ & $\begin{array}{l}\text { Increase the RAS/RT } \\
\text { Improve seed germination }\end{array}$ & {$[71]$} \\
\hline $\begin{array}{l}\text { P. fluorescens FAP2 } \\
\text { B. licheniformis B } 642\end{array}$ & Wheat & $\begin{array}{l}\text { Enhance vegetative growth } \\
\text { Enhance photosynthesis, chlorophyll content, } \\
\text { transpiration rate (E), internal } \mathrm{CO}_{2} \text { concentration (Ci), } \\
\text { stomatal conductance (gs), net photosynthetic rate (PN), } \\
\text { and leaf water potential (LWP) as compared to } \\
\text { uninoculated control }\end{array}$ & {$[62]$} \\
\hline
\end{tabular}

[49]. These facilitate enhanced nutrient and water uptake through improved root/shoot growth. EPS-producing rhizospheric bacteria increased water efficiency use by $63 \%$ by threefold increased soil aggregation around the wheat roots [74]. Similarly, EPS-producing strain Klebsiella sp. IG3 led to improved RAS permeability through increasing soil aggregation and water potential around the roots [75]. This discussion supports that plant growthpromoting microorganisms play a significant role in drought tolerance with various mechanisms [76] (Table 2).

\section{Role of EPS in Mitigation of Salinity Stress in Plants}

The problem of increased soil salinity has become a global concern. Some international agencies that have actively participated in data collection regarding soil salinity around the world include the United Nations Educational, Scientific and Cultural Organization - United Nations Environment Programme (UNESCOUNEP), the Food and Agriculture Organization (FAO), and the International Society of Soil Science (ISSS). According to the Soil Map of the World (FAO, 1971-1981), the problem of high soil salinity affects around 953 million hectares (Mha) worldwide. The FAO report on "Status of the World's Soil Resources" stated that more than a hundred countries worldwide with a total estimated area of about one billion hectares faces the problem of high soil salinity [77].

High soil salinity mainly occurs due to excessive use of chemical fertilizers and pesticides, lack of proper drainage systems and improper irrigation practices, and this high salt content in the soil turns out to be extremely damaging for crops [78]. Apart from drought, salinity is another common environmental stressor that adversely 
impacts plant growth and development and decreases crop yields in affected regions globally [79]. The negative effects on plant growth due to salinity can be attributed to osmotic stress, partial stomatal closure, or nutrient imbalance [80]. Some of these negative effects specifically include decreased energy and lipid metabolism, reduced capacity for chlorophyll content, photosynthesis, decrease in total nitrogen content, and reduced protein synthesis [80]. Salinity also causes oxidative stress in plants causing damage to protein, nucleic acid and lipids peroxidation resulting in loss of membrane integrity [81]. Salt stress-tolerant strains produce EPS in varying compositions and concentrations, enhancing germination and improving crop yields under environmental stress conditions $[70,82]$. EPS works as a physical barricade in the soil protecting roots and promoting plant growth under high salinity conditions $[72,83]$. EPS production by bacteria in high salinity soil enhances its physicochemical properties and promotes soil aggregate formation [83]. Microbes, especially bacteria, have the ability to impart salt-tolerance to plants and enhance their growth through various mechanisms in saline soil [84]. EPS binds with sodium ions thereby reducing the effects of high soil salinity and EPS produced by microbes mitigates salt stress by maintaining $\mathrm{Na}^{+} / \mathrm{K}^{+}$balance that helps plant to survive under unfavorable soil conditions $[85,86]$. EPS-producing salt-tolerant bacteria when inoculated in plants improved the ability of the plants to take up sodium, calcium, and potassium ions from the soil $[73,74]$. EPS chelates sodium ions from around the roots thereby preventing the ions from reaching the stem and decreasing sodium absorption from the soil [87]. EPS chelates sodium ions from around the roots thereby preventing the ions from reaching the stem and decreasing sodium absorption from the soil [88]. An increase in salt concentration also stimulates an increase in EPS production which further leads to biofilm production $[78,82,89]$ and further enhancement of $\mathrm{Na}^{+}$chelation. $\mathrm{NaCl}$ concentration in soil also determines the composition of EPS as increased rhamnose and trehalose were reported by Tewari and Arora [84]. These sugars help microbes to tolerate salt stress by providing carbon source, enhancing water retention.

Researchers have shown that both biofilm formation and EPS production result in several advantages to plants growing in a high salinity environment. They increase cell viability in the rhizosphere region thereby enhancing soil fertility and plant growth [88]. They protect plants from external stress, increase surface area for adhesion, provide high population densities, enhance plant tolerance to antimicrobial agents, and promote nutritional competition between microorganisms [90]. Various strategies adopted by microbes to alleviate salt stress include osmotic balancing, ion transport, and activating oxidative stress defense mechanisms [12, 90-92]. Also, microbes produce various phytohormones, ACC deaminase, siderophores and exopolysaccharides [92]. Studies using the halotolerant strain R. meliloti EFB1 showed that two EPSs, a succinoglycan (EPS I) and a galactoglucan (EPS II) are produced and regulated at the transcriptional level in response to soil salinity [93].

Upadhyay et al. [12] demonstrated that PGP traits such as phosphate solubilization, auxin production, sugar reduction, proline production, and total soluble sugar production were shown by EPS-producing salt-tolerant bacterial strains Bacillus sp. (SKU-3) and Paenibacillus sp. (SKU 11) which helped in increasing the plant biomass in inoculated plants when compared to uninoculated plants [12]. Also, under conditions of high salinity, greater bacterial enrichment was noticed in the rhizosphere region when compared to normal salinity conditions. All these strains belonged to the genera Bacillus, Burkholderia, Enterobacter, Microbacterium, and Paenibacillus and showed EPS and IAA production capability, which decreased with increase in soil salinity $[12,68]$.

Qurashi and Sabri [82] demonstrated that the EPS-producing salt-tolerant plant growth-promoting rhizosphere strains, Planococcus rifietoensis RT4 and Halomonas variabilis HT1, could stabilize soil structure and promote soil aggregation under high salinity conditions, which had a positive effect on growth of chickpea plant. EPS production by bacteria in the biofilm also helped in root colonization by salt-tolerant plant growthpromoting rhizhosheric bacteria. The two strains $P$. rifietoensis $\mathrm{RT} 4$ and $H$. variabilis $\mathrm{HT} 1$ produced increased EPS and biofilm formation under high salinity conditions which supported the growth of chickpea plant [82]. Atouie et al. [94] studied EPS-producing strains B. subtilis subsp. inaquosorum and Marinobacter lipolyticus SM19 (T) on increasing plant resistance to salt and drought stresses by decreasing $\mathrm{Na}^{+}$uptake and increasing the dry weight of root in wheat.

In a recent study, EPS-producing Pseudomonas PS01 strain upregulated the lipoxygenase (LOX2) gene in A. thaliana, which codes for a lipoxygenase that plays an important role in the jasmonic acid (JA) synthesis pathway. JA is known to accumulate in plants under salt stress conditions and act as a positive regulator of stressresponsive genes $[95,96]$. Additionally, EPS production by bacteria helps plants survive under high salinity conditions. The mutant that was produced by random transposon mutagenesis was used to study the changes responsible for stress tolerance, which included decreased EPS production, low tolerance to salinity, and reduced competitive fitness in the rhizosphere [96]. Salt-tolerant bacterial isolates such as Achromobacter denitirificans, Bacillus aryabhattai, and Ochrobactrum intermedium demonstrated increased ability to fix atmospheric nitrogen and increase phosphate solubilization and IAA production when exposed to salt stress of $200 \mathrm{mmol} / \mathrm{L}$. Based on their ability to produce EPS, these isolates demonstrated higher resistance to antibiotics and heavy metals along with increased expression of salt-responsive genes in the plant such as SOS1, NHX1, GIG, and BZ8. Therefore, inoculation of the rice plant with salt-tolerant plant growth-promoting bacteria can be a potentially good strategy for coastal agriculture [97]. Further exploration showed EPS with high glucose could chelate $\mathrm{Na}^{+}$present in saline soil, preventing its availability to the plant. Inoculation of B. tequilensis and B. aryabhattai strains increased photosynthesis, transpiration, and stomatal conductance of the plant leading to high yield under saline stress in rice crop [17].

Mesorhizobium alhagi is a soil bacterium that forms a symbiotic relationship with legumes, specifically forming nodules with the desert plant Alhagi sparsifolia, as revealed by the results of Mu et al. phenotypic analysis. It uses mannitol as a carbon source and produces a large quantity of EPS. EPS-deficient mutants of $M$. alhagi, CCNWXJ12-2 ${ }^{\mathrm{T}}$, which was constructed using transposon mutagenesis, demonstrated decreased tolerance to salt 
stress, low antioxidant capacity, and reduced cell motility when compared to the wild-type strain. This also proves that EPS plays a role in maintaining cellular sodium content and activity of antioxidant enzymes to optimum levels, which helps in adapting to high salinity [98]. EPS-producing bacteria (Azotobacter chroococcum) and melatonin alleviated salinity stress on faba bean plants by decreasing $\mathrm{Cl}^{-}$concentrations. Also, bacterial priming and meltonin enhanced N, P, and K concentrations; the proline content; relative water content RWC\%; and the $\mathrm{K}^{+} /$ $\mathrm{Na}^{+}$ratio [99]. Salt tolerance in Rhodopseudomonas palustris strains TN114 and PP803 is attributed to galacturonic acid, a polysaccharide $(\approx 18 \mathrm{kDa})$ present in EPS, chelates $\mathrm{Na}^{+}$cations from aqueous environment [100]. Similarly, the salt-tolerant plant growth-promoting R strains, Bacillus sp. (PM15), B. siamensis PM13, and B. methylotrophicus PM19 have demonstrated the ability to attenuate the adverse effects of high soil salinity in wheat plant [101,91]. Several bacterial genera, Pseudomonas, Bacillus, Burkholderia, Enterobacter, Microbacterium, Planococcus, Halomonas, and Azotobacter have been reported to produce EPS in salt stress condition [82, 102]. Also, they support plant growth by inducing indole acetic acid production, biological nitrogen fixation, solubilization of soil $\mathrm{P}$ and $\mathrm{K}$, and production of siderophores and hydrolyzing enzymes under salt stress condition [12]. Mohammad et al. [103] showed high PGP and biofilm-forming activity of Pseudomonas anguilliseptica SAW 24 and hence correlation between these traits under saline and non-saline conditions. Similarly, combined application of ACC deaminase and EPS-producing Bacillus isolates and Rhizobium improved faba beans seedling growth under saline conditions by accumulation of sugars and proteins [104]. Enterobacter sp. MN17 and Bacillus sp. MN54 improved plant-water relations in quinoa (Chenopodium quinoa) under saline stress [105]. Rhizobium and Pseudomonas co-inoculation in maize was reported to increase proline production and decreased electrolyte leakage along with maintenance of leaf relative water content, and uptake of $\mathrm{K}^{+}$, as a mechanism in imparting salt tolerance [106]. Aeromonas hydrophila/caviae MAS765, Bacillus insolitus MAS17, and Bacillus sp. strains MAS617, MAS620, and MAS820 restricted passive flow of $\mathrm{Na}^{+}$from the layer of soil clinging roots to stele in wheat crop [107]. A consortium of salt-tolerant Aeromonas spp. SAL-17 and SAL-21 produced Acyl homoserine lactones (AHLs), QS molecules, and sustained the growth of salt-tolerant and non-salt tolerant wheat genotypes in saline soil [108].

This discussion concludes that bacterial exopolysaccharides ameliorate salinity stress by chelating free $\mathrm{Na}^{+}$ion, making it available to plants, supporting soil aggregation and stability, enhancing biofilm formation, and contributing to water retention (Table 3). There are several reports on protection of plants in salinity by EPSproducing plant growth-promoting microorganisms, still, more studies are needed about change in physicochemical properties of EPS in saline environment.

\section{Role of EPS in Mitigation of Metal Stress in Plants}

Soil gets contaminated with heavy metals due to natural phenomena such as soil erosion, volcanic eruptions, weathering of minerals, and forest fires, or by anthropogenic activities such as excessive use of pesticides and chemical fertilizers, smelting, mining, automobile exhaust emissions, leather tanning, municipal waste disposal, textiles dyeing and processing, and manufacturing industrial activities [109]. Heavy metals are toxic in nature because they are non-biodegradable, mutagenic, carcinogenic, and teratogenic, have low bioavailability, and are highly soluble in aqueous environments [110]. The aqueous layer of the soil is a dynamic environment where chemical reactions, and circulation and transfer of heavy metals between bacteria, aqueous layer, and soil layer take place constantly [111]. Heavy metal stress has detrimental effects on plant growth by decreasing chlorophyll contents, blocking gas exchange factors and production of ROS, all of which impose oxidative stress [112].

Plant-associated microorganisms produce EPS and biosurfactants which help in maintaining soil structure and soil fertility in adverse toxic metal conditions [113]. Another study by Mishra et al. [112] reported that polysaccharides and lipopolysaccharides of EPS remove metal from rhizospheric soil by biosorption of metal ions owing to presence of anionic functional group. These groups include phosphate, hydroxyl, succinyl, and uronic acids. ESP can mobilize toxic metals by binding with heavy metals such as cadmium, lead, zinc, uranium, copper, and iron aluminum [112].

EPS affinity to heavy metals is due to electrostatic interactions which occur between heavy metal ions and surface functional groups of EPS such as hydroxyl and carboxyl. It binds with cationic heavy metals such as $\mathrm{Cd}^{2+}$, $\mathrm{Co}^{2+}, \mathrm{Pb}^{2+}$ and $\mathrm{Ni}^{2+}$ resulting in the formation of EPS-metal complexes [16]. Trivalent cations compete with divalent cations to bind with EPS, and trivalent cations form stronger bonds with EPS [114]. Cr (VI)-tolerant plant growth-promoting strain Cellulosimicrobium funkei KM032184 isolated from Phaseolus vulgaris L. showed tolerance to multiple metal and plant growth-promoting traits. Metal tolerance was due to entrapping of metal ions by the anionic molecules of EPS which restricts the mobility of metal ions to plants [115]. EPS- and ACCproducing Bacillus gibsonii PM11 and Bacillus xiamenensis PM14, isolated from sugarcane's rhizosphere, promoted growth of flax plant (Linum usitatissimum L.) under multi-metal contaminated soil through elevated phytoextraction of metals [116].

Cyanobacterial EPS helps in preventing direct contact between these toxic metals and plant cells [117]. Jittaquttipoka et al. [117] demonstrated four genes namely, sll0923, sll1581, slr1875, and sll5052, that are responsible for secretion of EPS which provide tolerance to Cynobacterium synechocystis PCC6803 against $\mathrm{NaCl}, \mathrm{CoCl}_{2}$, $\mathrm{CdSO}_{4}$, and iron starvation.

Many bacterial strains like Pseudomonas and Enterobacter play an important role in bioremediation of heavy metals. A study demonstrated the lead bioremediation properties of Pseudomonas sp. W6 isolated from hot water springs in Northeast India. This Pseudomonas strain showed a high capacity for adherence to metal substrates and soluble metals [118].

Gutehan et al. [119] isolated 66 EPS-producing plant growth-promoting bacteria with variable tolerance to Fe, 
Table 3. Applications of EPS-producing salt-tolerant bacteria.

\begin{tabular}{|c|c|c|c|}
\hline Microorganisms & Crops & PGP trait & References \\
\hline $\begin{array}{l}\text { Halmonas variabilis } \mathrm{HT} 1 \\
\text { Planococcus refietoensis } \mathrm{RT} 4\end{array}$ & Cicera rietinum & $\begin{array}{l}\text { Increase in fresh weight, dry weight, total soluble } \\
\text { sugars and protein contents } \\
\text { Increase soil aggregation and biofilm formation }\end{array}$ & {$[82]$} \\
\hline Rhizobium meliloti & Tomato & EPS with high succinoglycan and galactoglucon & [67] \\
\hline $\begin{array}{l}\text { Bacillus sp., (B. licheniformis, B. } \\
\text { pumilus, B. coagulans, and B. } \\
\text { insolitus) } \\
\text { Paenibacillus sp., (P. macerans) } \\
\text { Microbacterium sp. } \\
\text { Burkholderia cepacia } \\
\text { Enterobacter sp. }\end{array}$ & Wheat & $\begin{array}{l}\text { Rhizospheric soil aggregation } \\
\text { Decrease } \mathrm{Na}^{+} \text {uptake and root biofilm formation }\end{array}$ & {$[12]$} \\
\hline $\begin{array}{l}\text { Pseudomonas anguilliseptica SAW } \\
24\end{array}$ & Faba bean & Enhance plant height and fresh/dry weight & {$[81]$} \\
\hline Rhizobium and Pseudomonas & Zea Mays & $\begin{array}{l}\text { Increase proline production } \\
\text { Decrease electrolyte leakage along with } \\
\text { maintenance of leaf relative water content and } \\
\text { uptake of } \mathrm{K}^{+}\end{array}$ & {$[106]$} \\
\hline Bacillus isolates and Mesorhizobium & $\begin{array}{l}\text { Cicer arietinum } \\
\text { L. (Chickpea) }\end{array}$ & Reduce concentration of $\mathrm{Na}^{+}$in soil & {$[104]$} \\
\hline Azotobacter chroococcum & Vicia faba L. & $\begin{array}{l}\text { Enhanced } \mathrm{N}, \mathrm{P} \text {, and } \mathrm{K} \text { concentrations, the proline } \\
\text { content, } \mathrm{RWC} \% \text {, and the } \mathrm{K}^{+} / \mathrm{Na}^{+} \text {ratio }\end{array}$ & [99] \\
\hline Aeromonas spp. SAL-17 and SAL-21 & Wheat & $\begin{array}{l}\text { Increase in leaf proline content, nitrate reductase } \\
\text { activity, chlorophyll a/b, stomatal conductance, } \\
\text { transpiration rate, root length, and shoot length }\end{array}$ & {$[108]$} \\
\hline $\begin{array}{l}\text { Aeromonas hydrophila/caviae } \\
\text { MAS765, Bacillus insolitus MAS17, } \\
\text { and Bacillus sp. MAS617, MAS620, } \\
\text { and MAS } 820\end{array}$ & Wheat & $\begin{array}{l}\text { Restricted passive flow of } \mathrm{Na}^{+} \text {from the roots to } \\
\text { stele in wheat crop and large root surface covered } \\
\text { with soil }\end{array}$ & {$[107]$} \\
\hline $\begin{array}{l}\text { Marinobacter lipolyticus SM19 and } \\
\text { B. subtilis subsp. inaquosorum }\end{array}$ & Wheat & $\begin{array}{l}\text { Shoot and root dry weight } \\
\text { Restricted } \mathrm{Na}^{+} \text {uptake }\end{array}$ & {$[94][83]$} \\
\hline Pseudomonas aeruginosa PF07 & $\begin{array}{l}\text { Hellianthus } \\
\text { annuus }\end{array}$ & $\begin{array}{l}\text { Enhance Root Adhering Soil to Root Tissue ratio } \\
\text { (RAS/RT)) and texture of the soil } \\
\text { Increase porosity } \\
\text { Improve uptake of nutrients }\end{array}$ & {$[84]$} \\
\hline $\begin{array}{l}\text { Enterobacter sp. MN17 } \\
\text { and Bacillus sp. MN54 }\end{array}$ & $\begin{array}{l}\text { Quinoa } \\
\text { (Chenopodium } \\
\text { quinoa) }\end{array}$ & Improved plant-water relations & [105] \\
\hline $\begin{array}{l}\text { Rhodopseudomonaspalustris TN114 } \\
\text { and PP803 }\end{array}$ & - & Chelate $\mathrm{Na}^{+}$cations from aqueous environment & {$[100]$} \\
\hline
\end{tabular}

$\mathrm{Mn}, \mathrm{Cu}, \mathrm{Zn}$, and $\mathrm{Pb}, \mathrm{Fe}$ and $\mathrm{Mn}$ which promoted growth of Acacia in metal stress. Out of these, Paenibacillus polymyxa strain FB50 Acinetobacter calcoaceticus stain BS-27, P. putida strain BS-19, and P. fluorescens strain FB-49 showed $100 \%$ tolerance to all heavy metals. Paenibacillus spp and B. thuringiensis were also tolerant to heavy metals like $\mathrm{Cd}, \mathrm{Cu}$, and $\mathrm{Zn}$. Similarly, two plant growth-promoting rhizospheric bacterial strains, B. gibsonii PM11 and B. xiamenensis PM14, isolated from sugarcane's rhizosphere, showed tolerance to multiple metals $(\mathrm{Cd}, \mathrm{Cr}, \mathrm{Cu}$, $\mathrm{Mn}$, and $\mathrm{Zn}$ ) [116]. These are also reported to possess plant growth-promoting attributes like IAA, ACCdeaminase, EPS production and nitrogen fixing, and siderophore production under metal stress. Flax plant $(L$. usitatissimum L.) could survive and showed improved growth in metal stress when primed with B. gibsonii PM11 and B. xiamenensis PM14 [116].

The Halomonas species isolated from the rhizosphere of the true mangrove Avicennia marina secrete EPS which sequestered arsenic and salt in both in vitro and in vivo studies, proving EPS has a direct role in plant growth promotion in metal stress environment [120]. EPS-producing, cadmium- and chromium-tolerant strain Bacillus anthracis PM21 enhanced seed germination, root and shoot length and photosynthetic pigment in Sesabania sesban in metal-stressed conditions. Inoculation with this strain also increased activities of antioxidant enzymes superoxide dismutase, peroxidase, and catalase, and decreased proline content, electrolyte leakage and malondialdehyde concentration in seedlings [121] (Table 4). This discussion shows plant growth-promoting microorganisms with EPS production have significant ability for heavy metal bioremediation. Engineering or modifying such microbes for EPS production to enhance heavy metal removal can be useful for the growth of plants in metal stress environments [122, 123].

\section{Role of EPS in Mitigation of Temperature Stress in Plants}

High temperature-induced heat stress causes damage to crop plants, [124] subjecting global crop production to great peril [125]. Global warming could cause an increase in global temperature from 1.6 to $6^{\circ} \mathrm{C}$ by $2050 \mathrm{FAO}$ [46]. A rise by one degree in temperature will lead to $20 \%$ decrease in water resources and this is a major concern for agricultural productivity [126]. Climate change affects plant metabolism, seed germination, and seedling growth, 
Table 4. EPS-producing bacteria demonstrating metal tolerance.

\begin{tabular}{|c|c|c|c|c|}
\hline Microbial Strain & Metals & Plants & Roles of EPS & References \\
\hline $\begin{array}{l}\text { Cynobacterium } \\
\text { synechocystis PCC6803 }\end{array}$ & Cadmium, Cobalt & - & $\begin{array}{l}\text { Tolerance to stresses triggered by } \\
\mathrm{NaCl}, \mathrm{CdSO}_{4}, \mathrm{CoCl}_{2} \text {, or Fe starvation }\end{array}$ & {$[117]$} \\
\hline Pseudomonas sp. W6 & Lead & - & Bio-adsorption of lead & [118] \\
\hline $\begin{array}{l}\text { A. calcoaceticus } \mathrm{BS}-27 \\
\text { P. polymyxa } \mathrm{FB}-50 \\
\text { P. putida BS-19 } \\
\text { P. fluorescens } \mathrm{FB}-49\end{array}$ & $\begin{array}{l}\text { Iron, Manganese, } \\
\text { lead, Zinc, Copper }\end{array}$ & Acacia & $\begin{array}{l}\text { Increase root and shoot length, dry } \\
\text { biomass, and metal tolerance }\end{array}$ & [119] \\
\hline $\begin{array}{l}\text { Bacillus gibsonii PM11 } \\
\text { Bacillus xiamenensis } \\
\text { PM14 }\end{array}$ & $\begin{array}{l}\text { Iron, Manganese, } \\
\text { Cadmium, Zinc, } \\
\text { Copper, } \\
\text { Chromium }\end{array}$ & $\begin{array}{l}\text { Flax (Linum } \\
\text { usitatissimum } \\
\text { L.) }\end{array}$ & $\begin{array}{l}\text { Enhance plant growth and nutrient } \\
\text { availability by minimizing metal- } \\
\text { induced stress } \\
\text { Enhance phytoextraction of multi- } \\
\text { metals }\end{array}$ & {$[116]$} \\
\hline Bacillus anthracis PM21 & $\begin{array}{l}\text { Cadmium, } \\
\text { Chromium }\end{array}$ & Sesbania sesban & $\begin{array}{l}\text { Enhance seed germination, root and } \\
\text { shoot length and photosynthetic } \\
\text { pigment }\end{array}$ & {$[121]$} \\
\hline $\begin{array}{l}\text { Cellulosimicrobiumfunkei } \\
\text { KM032184 }\end{array}$ & Chromium & $\begin{array}{l}\text { Phaseolus } \\
\text { vulgaris } \mathrm{L}\end{array}$ & $\begin{array}{l}\text { Root Elongation, Shoot elongation, } \\
\text { Antioxidant, }\end{array}$ & [115] \\
\hline Halomonas species & Arsenic & $\begin{array}{l}\text { Avicennia } \\
\text { marina }\end{array}$ & $\begin{array}{l}\text { Arsenic bioadsprtion, } \\
\text { in vitro } \mathrm{Na}^{+} \text {ion sequestration and } \\
\text { antioxidant activity }\end{array}$ & {$[120]$} \\
\hline
\end{tabular}

photosynthesis, chloroplast metabolism thereby reducing crop yields [127]. At high temperatures $\left(30-38^{\circ} \mathrm{C}\right)$, delay in seed germination can be observed [120]. The reproductive stage of a plant is especially sensitive to high temperatures, and this has been demonstrated in chickpea [128], mungbean [129], sorghum [130], wheat [131], and lentil [132] plants. In tropical and temperate regions, flowering, number of flowers, and number of fruits in a plant are also affected by heat stress. Plant growth-promoting rhizosphere bacteria such as Pseudomonas produce EPS which serve as a defense mechanism for microorganisms to survive under stress conditions [133]. Therefore, this activity of such microorganisms helps attenuate the adverse effects of high temperatures on plant growth, development, and crop productivity [134]. Mukhtar et al. [135] showed an increase in the number of fruits and flowers in two varieties of tomato plant, i.e., Sweetie and Riogrande, upon inoculation with EPS-producing $B$. cereus, in high temperature stress. Plant growth-promoting microbes inoculation was found to improve physiological traits such as length of root and shoot, dry weight and fresh weight, and surface area of leaves, and biochemical traits such as chlorophyll content, relative water content, protein content, proline content, and antioxidant enzyme activities in the tomato plant when exposed to high temperature. Environmental heat stress induced changes in EPS production and production of new types of cellular proteins such as heat shock proteins. Heat shock proteins prevent aggregation, assist in protein refolding, and target abnormally folded proteins for degradation [136]. Nandal et al. [137] demonstrated the adaptive mechanism of Rhizobia species under heat stress conditions. At $43^{\circ} \mathrm{C}$, EPS production was higher in all 14 heat-resistant mutant strains as compared to the parent strain (PP201).

Nguyena et al. [138] demonstrated EPS-producing Bfidobacterium bifidum survived when exposed to a sublethally high temperature. Increased cell robustness, cell viability, and stress resistance, and a reduction in the net surface charge of microbial cells and survival against freeze-drying was observed. Pseudomonas sp. strain PsJN promoted growth in vitro and ex vitro, of various varieties of potato under heat stress conditions [139]. Al-Abd Daim et al. [140] evaluated management of heat stress in two wheat varieties (Olivin and Sids1) under heat stress conditions and revealed that the application of Bacillus amyloliquefaciens UCMB5113 or A. brasilense NO40 improved the growth of plants in heat stress. Later, in another set of experiments, Al-Abd Daim et al. [140] reported plant growth-promoting rhizospheric strain Bacillus velezensis 5113 inoculation resulted in a metabolic modulation and involvement of many regulatory proteins in wheat leaves to develop heat, cold and drought stress tolerance.

Another investigation on the role of two bacterial strains, B. aryabhattai $\mathrm{H} 26-2$ and B. siamensis $\mathrm{H} 30-3$ on mitigation of heat and drought stress on two cultivars ('Ryeokkwang' and 'Buram-3-ho') of Chinese cabbage suggested exopolysaccharides as important bacterial determinants on alleviating not only these stresses but also on biocontrol activity against soft rot caused by Pectobacterium carotovorum subsp. carotovorum PCC21[141].

Heat stress $\left(45^{\circ} \mathrm{C}\right)$ affected knockout mutants Shinorizobium meliloti HslUV and ClpXP proteases and reduced EPS production and shoot dry weight in Medicago sativa suggesting the role of EPS in symbiosis during heat stress [142]. Similarly, Bradyrhizobium diazoefficiens USDA110, responsible for nitrogen fixation in soybean, accumulates poly-3-hydroxybutyrate (PHB), a source of carbon/energy during starvation, infection, and nitrogen fixation conditions. PHB synthesis involves pha gene regulated by PhaR transcription factor. Inactivation of this factor decreases PHB accumulation and cell yield but enables accumulation of EPS and heat stress tolerance. This suggests a direct role of EPS in heat stress tolerance [142, 143] (Table 5).

There are still many mechanisms needing to be explored for abiotic stress responses using plant growthpromoting rhizospheric bacteria and EPS and applied plant growth-promoting microorganism (PGPM) bacterial strains shown to improve crops growing under heat-stressed conditions.

Like high temperature stress, plant productivity is also deteriorated under cold stress. Psychrophiles and 
Table 5. EPS-producing PGPR imparting tolerance to heat stress.

\begin{tabular}{|c|c|c|c|}
\hline Microorganisms & Crops & Roles of EPS & References \\
\hline Bacillus cereus & Tomato & $\begin{array}{l}\text { Increase the number of flowers and fruits } \\
\text { Increase chlorophyll, proline and antioxidants }\end{array}$ & {$[135]$} \\
\hline $\begin{array}{l}\text { Bacillus amyloliquefaciens } \\
\text { UCMB5113 } \\
\text { Azospirillum brasilense NO40 }\end{array}$ & Wheat & $\begin{array}{l}\text { Increase HSP } 26 \text { and chlorophyll content } \\
\text { Accumulate GABA and modulate metabolic pathways }\end{array}$ & [140] \\
\hline Pseudomonas sp. AKM-P6 & Sorghum & Enhance tolerance of sorghum seedlings to elevated temperatures & {$[134]$} \\
\hline Rhizobium sp. (Cajanus) & Legume & Heat shock protein (Hsp) of $63-74 \mathrm{kDa}$ & [29] \\
\hline Pseudomonas sp. PsJN & Potato & Promote growth & [139] \\
\hline $\begin{array}{l}\text { Bacillus aryabhattai } \mathrm{H} 26-2 \\
\text { and Bacillus siamensis } \mathrm{H} 30-3\end{array}$ & $\begin{array}{l}\text { Chinese } \\
\text { cabbage }\end{array}$ & $\begin{array}{l}\text { Leaf abscisic acid (ABA) content and reduced stomatal opening } \\
\text { after stresses treatments, } \\
\text { Biocontrol activity against soft rot }\end{array}$ & [140] \\
\hline Shinorizobium meliloti & $\begin{array}{l}\text { Medicago } \\
\text { sativa }\end{array}$ & Affect symbiosis during heat stress & [142] \\
\hline $\begin{array}{l}\text { Bradyrhizobium } \\
\text { diazoefficiens USDA } 110\end{array}$ & Soybean & Survival in starvation & [143] \\
\hline
\end{tabular}

psychrotolerant microorganisms colonize permanently cold habitats, such as the polar regions, high altitudes and the deep sea and grow at temperatures ranging from subzero to $15^{\circ} \mathrm{C}$. At high-altitude, psychrotolerant microbes sustain and maintain functionality in cold-temperature conditions, while growing optimally at warmer temperatures. Low temperature primarily causes irreversible freezing injury which includes dysfunction of plasma membrane and cellular dehydration [144]. Plant growth-promoting bacteria present within the root zone stimulate the increase in density of root hairs through various phytohormones and hence increase the uptake of water and nutrients. There are investigations reporting on the role of such microorganisms in protecting crops grown at low temperature. Psychrophilic Bacillus strains CJCL2 and RJGP41 were able to significantly improve wheat growth positively by regulating abscisic acid, lipid peroxidation and proline accumulation pathways [145]. In other studies, Burkholderia phytofirmans PsJN could tolerate cold stress by inducing high concentration of total reducing sugars, glucose, and proline on bacterization of grapevine [146, 147]. A consortium of strains $(B$. cereus AR156, B. subtilis SM21, and Serratia sp. XY21 also increased accumulation of soluble sugar, proline, and osmotin, enhanced the antioxidant defense system, and activated stress-related genes in tomato at chilling shock of $4^{\circ} \mathrm{C}$ [148]. Bacterization of wheat with psychrotolerant Pseudomonas at cold temperature alleviated cold stress by improving chlorophyll, anthocyanin, free proline, total phenolics, starch content, physiologically available iron, proteins, and amino acids. Other physiological traits like increased EPS, relative water content, reduced membrane injury (electrolyte leakage), and $\mathrm{Na}^{+} / \mathrm{K}^{+}$ratio also improved [144]. However, few studies are available addressing the exact role of EPS-induced protection under cold/chilling stress on plants.

The above discussion supports that EPS-producing microorganisms are key players in sustaining and increasing the productivity of the existing agro-ecosystem through myriad roles under varied abiotic stress conditions (Fig. 3 Graphical Abstract).

\section{Conclusion and Future Perspective}

Agricultural productivity and crop yields can be affected by various environmental stressors such as drought, salinity, high temperatures, and heavy metals, all of which adversely affect plant growth and development, and eventually lead to global food scarcity. Recent investigations have identified several species of bacteria that impart stress tolerance properties to plants through various activities such as EPS production and biofilm formation, which help increase the nutrient uptake and water retention capacity of plants. These PGP bacteria have been extensively studied as bio-inoculants used to promote plant growth and seed germination in regions of heavy environmental stress. They have been demonstrated to possess several PGP traits such as the production of siderophores, IAA, phytohormones and EPS that make plants resistant to environmental stress. Although the review of literature has shown promising results in this area of research, further studies and field trials are needed to characterize the PGP attributes of EPS produced by microorganisms under different stress conditions that are beneficial to plant growth and metabolism. Also, elaborate research is needed on the reciprocal effect of abiotic stress and EPS composition and the physicochemical nature of EPS under such stress conditions. These studies would help to provide tools for alleviating abiotic stress in agricultural crops. The combined use of EPS-producing bacteria offers a promising strategy for multiple abiotic stress management for crop plants. Additionally, bacterial EPS is appropriate for maintaining soil composition, nutrients and fertility to improve plant growth and crop yields.

\section{Acknowledgments}

The authors thank the authorities of Amity University Uttar Pradesh for providing the opportunity to prepare this review article.

\section{Conflict of Interest}

The authors have no financial conflicts of interest to declare. 


\section{References}

1. Raza A, Razzaq A, Mehmood SS, Zou X, Zhang X, Lv Y, et al. 2019. Impact of climate change on crops adaptation and strategies to tackle its outcome: a review. Plants (Basel) 30: 8: 34.

2. Lesk C, Rowhani P, Ramankutty N. 2016. Influence of extreme weather disasters on global crop production. Nature 529: 84-87

3. Etesami H, Beattie GA. 2017. Plant-microbe interactions in adaptation of agricultural crops to abiotic stress conditions. pp. 163200. In: Probiotics and Plant Health. Springer, Singapore.

4. Fita A, Rodríguez-Burruezo A, Boscaiu M, Prohens J, Vicente O. 2015. Breeding and domesticating crops adapted to drought and salinity: a new paradigm for increasing food production. Front. Plant Sci. 6: 978.

5. Basu A, Prasad P, Das SN, Kalam S, Sayyed RZ, Reddy MS, et al. 2021. Plant Growth Promoting Rhizobacteria (PGPR) as green bioinoculants: recent developments, constraints, and prospects. Sustainability 13: 1140.

6. Bashan Y, de-Bashan LE, Prabhu SR. Hernandez J-P. 2014. Advances in plant growth-promoting bacterial inoculant technology: formulations and practical perspectives (1998-2013). Plant Soil 378: 1-33.

7. Vejan P, Abdullah R, Khadiran T, Ismail S. 2016. Role of plant growth promoting rhizobacteria in agricultural sustainability-A review. Molecules 21: 573 .

8. Paulin MM, Novinscak A, Lanteigne C, Gadkar VI, Filion M.2017. Interaction between 2,4-diacetylphloroglucinol- and hydrogen cyanide-producing Pseudomonas brassicacearum LBUM300 and Clavibacter michiganensis subsp. michiganensis in the tomato rhizosphere. Appl. Environ. Microbiol. 83: e00073-17.

9. Prabhukarthikeyan SR, Keerthana U, Raguchander T. 2018. Antibiotic-producing Pseudomonas fluorescens mediates rhizome rot disease resistance and promotes plant growth in turmeric plants. Microbiol. Res. 210: 65-73.

10. Liu XM, Zhang H. 2015. The effects of bacterial volatile emissions on plant abiotic stress tolerance. Front. Plant Sci. 6: 774.

11. Khan N, Bano A, Rahman MA, Guo J. 2019. Comparative physiological and metabolic analysis reveals a complex mechanism involved in drought tolerance in chickpea (Cicer arietinum L.) induced by PGPR and PGRs. Sci. Rep. 9: 2097.

12. Upadhyay SK, Singh J S, Saxena A K, Singh D P. 2012. Impact of PGPR inoculation on growth and antioxidant status of wheat under saline conditions. Plant Biol. 14: 605-611.

13. Yadav VK, Raghav M, Sharma SK and Bhagat N. 2020. Rhizobacteriome: promising candidate for conferring drought tolerance in crops, J. Pure Appl. Microbiol. 14: 73-92.

14. Boonchai R, Kaewsuk J, Seo G. 2014. Effect of nutrient starvation on nutrient uptake and extracellular polymeric substance for microalgae cultivation and separation. Desalin. Water Treat. 55: 360-367.

15. Ilyas N, Mumtaz K, Akhtar N, Yasmin H, Sayyed RZ, Khan W, et al. 2020. Exopolysaccharides producing bacteria for the amelioration of drought stress in wheat. Sustainability 12: 8876 .

16. Sayyed RZ, Patel PR, Shaikh SS. 2015. Plant growth promotion and root colonization by EPS producing Enterobacter sp. RZS5 under heavy metal contaminated soil. Indian J. Exp. Biol. 53: 116-123.

17. Shultana R, Tan Kee Zuan A, Yusop MR, Mohd Saud H, Ayanda AF. 2020. Effect of Salt-tolerant bacterial inoculations on rice seedlings differing in salt-tolerance under saline soil conditions. Agronomy 10: 1030.

18. Shaik. Zulfikar Ali, Vardharajula Sandhya, Minakshi Grover, Venkateswar Rao Linga, Venkateswarlu Bandi. 2011. Effect of inoculation with a thermotolerant plant growth promoting Pseudomonas putida strain AKMP7 on growth of wheat (Triticum spp.) under heat stress. J. Plant Interact. 4: 239-246.

19. Vardharajula S, Ali S Z. 2015. The production of exopolysaccharide by Pseudomonas putida GAP-P45 under various abiotic stress conditions and its role in soil aggregation. Microbiology 84: 512-519.

20. Saha I, Datta S, Biswas D. 2020. Exploring the role of bacterial extracellular polymeric substances for sustainable development in agriculture. Curr. Microbiol. 77: 3224-3239.

21. Mathur P, Roy S. 2021. Insights into the plant responses to drought and decoding the potential of root associated microbiome for inducing drought tolerance. Physiol. Plant. 172: 1016-1029.

22. Roca C, Alves V D, Freitas F, Reis MA. 2015. Exopolysaccharides enriched in rare sugars: bacterial sources, production, and applications. Front. Microbiol. 6: 288.

23. Mishra A, Jha B. 2013. Microbial exopolysaccharides. In Rosenberg E, DeLong EF, Lory S, Stackebrandt E, Thompson F (eds.), The Prokaryotes. Springer, Berlin, Heidelberg.

24. Alami Y, Achouak W, Marol C, Heulin T. 2000. Rhizosphere soil aggregation and plant growth promotion of sunflowers by exopolysaccharide producing Rhizobium sp. strain isolated from sunflower roots. Appl. Environ. Microbiol. 66: 33933398.108.

25. Schmid J, Sieber V, Rehm B. 2015. Bacterial exopolysaccharides: biosynthesis pathways and engineering strategies. Front. Microbiol. 6: 496

26. Flemming HC, Wingender J. 2001. Relevance of microbial extracellular polymeric substances (EPSs)-parts I: structural and ecological aspects. Water Sci. Technol. 43: 1-8

27. Czaczyk K, Myszka K. 2007. Biosynthesis of extracellular polymeric substances (EPS) and its role in microbial biofilm formation. Polish J. Environ. Stud. 16: 799-806.

28. Donot F, Fontana A, Baccou JC, Schorr-Galindo S. 2012. Microbial exopolysaccharides: main examples of synthesis, excretion, genetics and extraction. Carbohydr. Polym. 87: 951-962.

29. Sutherland IW. 2001. Microbial polysaccharides from Gram-negative bacteria. Int. Dairy J. 11: 663-674.

30. Velmourougane K, Prasanna R, Saxena AK 2017. Agriculturally important microbial biofilms: present status and prospects. J. Basic Microbiol. 57: 548-573.

31. More T T, Yadav J S S, Yan S, Tyagi R D, Surampalli R Y. 2014. Extracellular polymeric substances of bacteria and their potential environmental applications. J. Environ. Manage. 144: 1-25.

32. Laspidou CS, Rittmann BE. 2002. A unified theory for extracellular polymeric substances, soluble microbial products, and active and inert biomass. Water Res. 36: 2711-20.

33. Drogue B, Combes-Meynet E, Moënne-Loccoz Y, Wisniewski-Dyé F, Prigent-Combaret C. 2013. "Control of the cooperation between plant growth-promoting rhizobacteria and crops by rhizosphere signals," in Vol. 1 and 2, pp. 281-294. Mol. Microb. Ecol. Rhizosphere, ed. F. J. de Bruijn (NJ, USA: John Wiley \& Sons, Inc.).

34. Prigent-Combaret C. 2013. "Control of the cooperation between plant growth-promoting rhizobacteria and crops by rhizosphere signals," in Vol. 1 and 2, pp. 281-294. Molecular Microbial Ecology of the Rhizosphere, ed. F. J. de Bruijn (NJ, USA: John Wiley \& Sons, Inc.).

35. Smith DL, Gravel V, Yergeau E. 2017. Editorial: signaling in the phytomicrobiome. Front. Plant Sci. 8: 611.

36. Miller MB, Bassler BL. 2001.Quorum sensing in bacteria. Annu. Rev. Microbiol. 55: 165-199.

37. Waters CM, Bassler BL. 2005. Quorum sensing: cell-to-cell communication in bacteria. Annu. Rev. Cell Dev. Biol. 21: 319-346.

38. Von Bodman SB, Majerczak DR, Coplin DL. 1998. A negative regulator mediates quorum-sensing control of exopolysaccharide production in Pantoea stewartii subsp. stewartii. Proc. Natl. Acad. Sci. USA 95: 7687-7692.

39. Kalia VC, Gong C, Patel SKS, Lee JK. 2021. Regulation of plant mineral nutrition by signal molecules. Microorganisms 9: 774. 
40. Rosier A, Medeiros FHV, Bais HP. 2018. Defining plant growth promoting rhizobacteria molecular and biochemical networks in beneficial plant-microbe interactions. Plant Soil 428: 35-55.

41. Costa OYA, Raaijmakers JM, Kuramae EE. 2018. Microbial extracellular polymeric substances: ecological function and impact on soil aggregation. Front. Microbiol. 23: 1636.

42. Martin JP. 1971 Decomposition and binding action of polysaccharides in soil. Soil Biol. Biochem. 3: 33-41.

43. Hillel D. 1982. Introduction to soil Physics. Academic Press Limited, 24-28 Oval Road, London.

44. Sengupta S, Dey S. 2019. Microbial exo-polysaccharides (EPS): role in agriculture and environment. Agric. Food 1: 4-8M.

45. Seleiman MF, Al-Suhaibani N, Ali N, Akmal M, Alotaibi M, Refay Y, et al. 2021. Drought stress impacts on plants and different approaches to alleviate its adverse effects. Plants 10:259.

46. FAO. 2020. World Food and Agriculture - Statistical Yearbook 2020. Rome.

47. Bouskill, NJ, Wood TE, Baran R, Ye Z, Bowen B P, Lim H, et al. 2016b. Below ground response to drought in a tropical forest soil. I. Changes in microbial functional potential and metabolism. Front. Microbiol. 7: 525.

48. Kaci Y, Heyraud A, Barakat M and Heulin T. 2005. Isolation and identification of an EPS-producing Rhizobium strain from arid soil (Algeria): characterization of its EPS and the effect of inoculation on wheat rhizosphere soil structure. Res. Microbiol. 156: $522-531$.

49. Konnova Svetlana, Brykova O, Sachkova O. Egorenkova I. Ignatov V. 2001. Protective role of the polysaccharide-containing capsular components of Azospirillum brasilense. Microbiology 70: 436-440.

50. Kohler J. Fuensanta C. Roldan, A. 2009. Effect of drought on the stability of Rhizosphere soil aggregates of Lactuca sativa grown in a degraded soil inoculated with PGPR and AM fungi. Appl. Soil Ecol. 42: 160-165.

51. Kohler J, Caravaca F. Carrasco L. Roldan A. 2006. Contribution of Pseudomonas mendocina and Glomus intraradices to aggregate stabilization and promotion of biological fertility in rhizosphere soil of lettuce plants under field conditions. Soil Use Manage. 22: 298-304.

52. Sandhya V, Ali SK, Minakshi G, Reddy G. Venkateswarlu B. 2009. Alleviation of drought stress effects in sunflower seedlings by the exopolysaccharides producing Pseudomonas putida strain GAPP45. Biol. Fertil. Soils 46: 17-26.

53. Vardharajula S, Sk Z A. 2014. Exopolysaccharide production by drought tolerant Bacillus spp. and effect on soil aggregation under drought stress. J. Microbiol. Biotechnol. Food Sci. 4: 51-57.

54. Sayyed RZ, Jamadar D, Patel PR. 2011 Production of Exopolysaccharide by Rhizobium sp. Indian J. Microbiol. 51: 294-300.

55. Aureen, LG, Saroj B. 2009. Sand aggregation by exopolysaccharide producing Microbacterium arborescens-AGSB. Curr. Microbiol. 58: 616-621.

56. Naseem H, Bano A. 2014. Role of plant growth-promoting rhizobacteria and their exopolysaccharide in drought tolerance of maize. J. Plant Interact. 9: 689-701.

57. Batool T, Ali S, Seleiman MF, Naveed NH, Ali A, Ahmed K, et al. 2020. Plant growth promoting rhizobacteria alleviates drought stress in potato in response to suppressive oxidative stress and antioxidant enzymes activities. Sci. Rep. 10: 16975

58. Hussain M B, Zahir ZA, Asghar HN, Asghar M. 2014. Can catalase and exopolysaccharides producing rhizobia ameliorate drought stress in wheat? Int. J. Agric. Biol. 16: 3-13

59. Zhang X, Yang Z, Li Z. Zhang F, Hao L. 2020. Effects of drought stress on physiology and antioxidative activity in two varieties of Cynanchum thesioides. Braz. J. Bot. 43: 1-10.

60. Khan N, Bano A. 2019. Exopolysaccharide producing rhizobacteria and their impact on growth and drought tolerance of wheat grown under rainfed conditions. PLoS One 14: e0222302.

61. Yadav J, Verma JP, Tiwari K N. 2010. Effect of plant growth promoting Rhizobacteria on seed germination and plant growth Chickpea (Cicer arietinum L) under in vitro condition Biological Forum. Int. J. 2: 15-18.

62. Ansari FA, Ahmad I. 2019. Fluorescent pseudomonas-FAP2 and Bacillus licheniformis interact positively in biofilm mode enhancing plant growth and photosynthetic attributes. Sci. Rep. 9: 4547.

63. Ali SZ, Sandhya V, Venkateswar Rao L. 2014. Isolation and characterization of drought-tolerant ACC deaminase and exopolysaccharide-producing fluorescent Pseudomonas sp. Ann. Microbiol. 64: 493-502.

64. Lim JH, Kim SD. 2013. Induction of drought stress resistance by multi-functional PGPR Bacillus licheniformis K11 in pepper. Plant Pathol. J. 29: 201-208.

65. Khan N, Bano A, Curá JA. 2020. Role of beneficial microorganisms and salicylic acid in improving rainfed agriculture and future food safety. Microorganisms 8: 1018.

66. Lu X, Liu SF, Yue L, Zhao X, Zhang Y-B, Xie Z-K, et al. 2018. Epsc involved in the encoding of exopolysaccharides produced by Bacillus amyloliquefaciens FZB42 act to boost the drought tolerance of Arabidopsis thaliana. Int. J. Mol. Sci. 19: 3795.

67. Wang DC, Jiang CH, Zhang LN, Chen L, Zhang XY, Guo JH. 2019. Biofilms positively contribute to Bacillus amyloliquefaciens 54induced drought tolerance in tomato plants. Int. J. Mol. Sci. 20: 6271.

68. Ghosh D, Gupta A, Mohapatra S. 2019. A comparative analysis of exopolysaccharide and phytohormone secretions by four drought-tolerant rhizobacterial strains and their impact on osmotic-stress mitigation in Arabidopsis thaliana. World J. Microbiol. Biotechnol. 35: 90

69. Igiehon NO, Babalola OO, Aremu BR. 2019. Genomic insights into plant growth promoting rhizobia capable of enhancing soybean germination under drought stress. BMC Microbiol. 19: 159

70. Susilowati A, Puspita AA, and Yunus, A. 2018. Drought resistant of bacteria producing exopolysaccharide and IAA in rhizosphere of soybean plant (Glycine max) in Wonogiri Regency Central Java Indonesia. IOP Conf. Series: Earth and Environmental Science 142 (2018) 012058

71. Niu X, Song L, Xiao Y, Ge W. 2018. Drought-tolerant plant growth-promoting rhizobacteria associated with foxtail millet in a semiarid agroecosystem and their potential in alleviating drought stress. Front. Microbiol. 8: 2580

72. Cho SM, Anderson AJ, Kim YC. 2018. Extracellular polymeric substances of Pseudomonas chlororaphis 06 induce systemic drought tolerance in plants. Res. Plant Dis. 24: 242-247.2018.

73. Vardharajula S, Ali SkZ. 2014. Exopolysaccharide production by drought tolerant Bacillus spp. and effect on soil aggregation under drought stress. J. Microbiol. Biotechnol. Food Sci. 4: 51-57.

74. Timmusk S, Abd El-Daim IA, Copolovici L, Tanilas T, Kännaste A, Behers L, et al. 2014. Drought-tolerance of wheat improved by rhizosphere bacteria from harsh environments: enhanced biomass production and reduced emissions of stress volatiles. PLoS One 9: e96086.

75. Gontia-Mishra I, Sapre S, Sharma A. Tiwari S. 2016. Amelioration of drought tolerance in wheat by the interaction of plantgrowthpromoting rhizobacteria. Plant Biol.18: 992-1000.

76. Camaille M, Fabre N, Clément C, Ait Barka E. 2021.Advances in wheat physiology in response to drought and the role of plant growth promoting rhizobacteria to trigger drought tolerance. Microorganisms 9: 687.

77. FAO, ITPS, GSBI, CBD and EC. 2020. State of knowledge of soil biodiversity - Status, challenges and potentialities, Report 2020. Rome, FAO.

78. Deng J, Orner EP, Chau JF, Anderson EM, Kadilak AL, Rubinstein RL, et al. 2015. Synergistic effects of soil microstructure and bacterial EPS on drying rate in emulated soil micromodels. Soil Biol. Biochem. 83: 116-124. 
79. Ma Y, Dias MC, Freitas H. 2020. Drought and salinity stress responses and microbe-induced tolerance in plants. Front. Plant Sci. 11: 591911.

80. Parida S K, and Das A B. 2005. Salt tolerance and salinity effects on plants. Ecotoxicol. Environ. Safety 60: 324-349.

81. Gupta B, Huang B. 2014. Mechanism of salinity tolerance in plants: physiological, biochemical, and molecular characterization. Int. J. Genomics 2014: 701596.

82. Qurashi AW, Sabri AN. 2012a. Bacterial exopolysaccharide and biofilm formation stimulate chickpea growth and soil aggregation under salt stress. Braz. J. Microbiol. 43: 1183-1191.

83. Minah B, Hazarin Subair F. 2015. Isolation and Screening bacterial exopolysaccharide (EPS) from potato rhizosphere in highland and the potential as a producer indole acetic acid (IAA). Procedia Food Sci. 3: 74-81.

84. Tewari S, Arora NK. 2014a. Multifunctional exopolysaccharides from Pseudomonas aeruginosa PF23 involved in plant growth stimulation, biocontrol and stress amelioration in sunflower under saline conditions. Curr. Microbiol. 69: 484-494.

85. Singh RP, Jha PN.2016. A halotolerant bacterium Bacillus licheniformis HSW-16 augments induced systemic tolerance to salt stress in wheat plant (Triticum aestivum). Front. Plant Sci. 7: 1890.

86. Pawar ST, Amarsinh A. Bhosale, Trishala B. Gawade, Nale TR. 2013. Isolation, screening and optimization of exopolysaccharide producing bacterium from saline soil. J. Microbiol. Biotechnol. Res. 3: 24-31.

87. Choudhary DK, Kasotia A, Jain S, Vaishnav A, Kumari S, Sharma KP, et al. 2015. Bacterial-mediated tolerance and resistance to plants under abiotic and biotic stress. J. Plant Growth Regul. 35: 276-300.

88. Ashraf M, Berge SH, Mahmood OT. 2004. Inoculating wheat seedling with exopolysaccharides-producing bacteria restrict sodium uptake and stimulates plant growth under salt stress. Biol. Fertil Soils 40: 157-162.

89. Arora M, Kaushik A, Rani N, Kaushik CP. 2010. Effect of cyanobacterial exopolysaccharides on salt stress alleviation and seed germination. J. Environ. Biol. 31: 701-704.

90. Ha-Tran DM, Nguyen TTM, Hung SH, Huang E, Huang CC. 2021. Roles of plant growth-promoting Rhizobacteria (PGPR) in stimulating salinity stress defense in plants: a review. Int. J. Mol. Sci. 22: 3154 .

91. Yasmeen T, Ahmad A, Arif MS, Mubin M, Rehman K, Shahzad SM, et al. 2020. Biofilm forming rhizobacteria enhance growth and salt tolerance in sunflower plants by stimulating antioxidant enzymes activity. Plant Physiol. Biochem. 156: 242-256.

92. Bhat MA, Kumar V, Bhat MA, Wani IA, Dar FL, Farooq I, et al. 2020. Mechanistic Insights of the interaction of Plant GrowthPromoting Rhizobacteria (PGPR) with plant roots toward enhancing plant productivity by alleviating salinity stress. Front. Microbiol. 20: 1952.

93. Lloret J, Wulff BB, Rubio JM, Downie J A, Bonilla I, Rivilla R. 1998. Exopolysaccharide II production is regulated by salt in the halotolerant strain Rhizobium meliloti EFB1. Appl. Environ. Microbiol. 64: 1024-1028.

94. Atouei M T, Pourbabaee A A, Shorafa M. 2019. Alleviation of salinity stress on some growth parameters of wheat by exopolysaccharide-producing bacteria. Ir. J. Sci. Technol. Trans. A. 43: 2725-2733.

95. Chu TN, Tran BTH, Van Bui L, Hoang MTT. 2019. Plant growth-promoting rhizobacterium Pseudomonas PS01 induces salt tolerance in Arabidopsis thaliana. BMC Res. Notes 12: 11

96. Wang J, Song L, Gong X, Xu J, Li M. 2020. Functions of jasmonic acid in plant regulation and response to abiotic stress. Int. J. Mol. Sci. 21: 1446.

97. Sultana S, Paul SC, Parveen S, Alam S, Rahman N, Jannat B, et al. 2020. Isolation and identification of salt-tolerant plant-growthpromoting rhizobacteria and their application for rice cultivation under salt stress. Can. J. Microbiol. 66: 144-160.

98. Liu X, Luo Y, Li Z, Wang J, Wei G. 2017. Role of exopolysaccharide in salt stress resistance and cell motility of Mesorhizobium alhagi CCNWXJ12-2 ${ }^{\mathrm{T}}$. Appl. Microbiol. Biotechnol. 101:2967-2978.

99. Abd El-Ghany, Mona FA Attia, Magdy. 2020. Effect of exopolysaccharide-producing bacteria and melatonin on faba bean production in saline and non-saline soil agronomy. 10:316.

100. Nunkaew T, Kantachote D, Nitoda T, Kanzaki H, Ritchie RJ. 2015. Characterization of exopolymeric substances from selected Rhodopseudomonas palustris strains and their ability to adsorb sodium ions. Carbohydr. Polym. 22: 115: 334-41.

101. Amna Xia Y, Farooq MA, Javed MT, Kamran MA, Mukhtar T, Ali J, et al. 2020. Multi-stress tolerant PGPR Bacillus xiamenensis PM14 activating sugarcane (Saccharum officinarum L.) red rot disease resistance. Plant Physiol. Biochem. 151: 1640-1649.

102. Oosten V, Stasio MJ. Cirillo ED, Silletti V, Ventorino S, Pepe V, Raimondi O, Maggio G A. 2018. Root inoculation with Azotobacter chroococcum 76A enhances tomato plants adaptation to salt stress under low N conditions. BMC Plant Biol. 18:205.

103. Mohammad A F. 2018. Effectiveness of exopolysaccharides and biofilm forming plant growth promoting rhizobacteria on salinity tolerance of faba bean (Vicia faba L.). Afr. J. Microbiol. Res. 12: 399-404.

104. Kumari P and Khanna V. 2015. ACC-deaminase and EPS production by salt tolerant rhizobacteria augment growth in chickpea under salinity stress. Int. J. Bio-resource Stress Manage. 6: 558-565.

105. Yang A, Akhtar SS, Iqbal S, Amjad M, Naveed M, Zahir ZA, et al. 2016. Enhancing salt tolerance in quinoa by halotolerant bacterial inoculation. Funct. Plant Biol. 43: 632-642.

106. Bano A and Fatima M. 2009. Salt tolerance in Zea mays(L). following inoculation with Rhizobium and Pseudomonas. Biol. Fertil. Soils 45: 405-413.

107. Ashraf M, Ahmad MSA, Ozturk M, Aksoy A. 2012. Crop improvement through different means. In Ashraf et al. (eds.), pp. 1-15. Crop Production for Agricultural Improvement, Springer.

108. Nawaz MS, Arshad A, Rajput L, Fatima K, Ullah S, Ahmad M, et al. 2020. Growth-stimulatory effect of quorum sensing signal molecule $\mathrm{N}$-Acyl-Homoserine lactone-producing multi-trait Aeromonas spp. on wheat genotypes under salt stress. Front. Microbiol. 29: 11:553621.

109. Chibuike GU, Obiora SC 2014. Heavy metal polluted soils: effect on plants and bioremediation methods. Appl. Environ. Soil Sci. 2014: 1-12.

110. Adrees M, Ali S, Rizwan M, Zia-Ur-Rehman M, Ibrahim M, Abbas F, et al. 2015. Mechanisms of silicon-mediated alleviation of heavy metal toxicity in plants: a review. Ecotoxicol. Environ. Saf. 119: 186-97.

111. Violante A, Cozzolino V, Perelomov L, Caporale AG, Pigna M. 2010. Mobility and bioavailability of heavy metals and metalloids in soil environments. J. Soil. Sci. Plant Nutr. 10: 268-292.

112. Mishra J, Singh R, Arora N K. 2017. Alleviation of heavy metal stress in plants and remediation of soil by rhizosphere microorganisms. Front. Microbiol. 8: 1706

113. Ayangbenro AS, Babalola OO. 2017. A New strategy for heavy metal polluted environments: a review of microbial biosorbents. Int. J. Environ. Res. Public Health 14: 94.

114. Dobrowolski R, Szcześ A, Czemierska M, Jarosz-Wikołazka A. 2017. Studies of cadmium (II), lead (II), nickel (II), cobalt (II) and chromium (VI) sorption on extracellular polymeric substances produced by Rhodococcus opacus and Rhodococcus rhodochrous. Bioresour. Technol. 225: 113-120.

115. Karthik C, Elangovan N, Kumar TS, Govindharaju S, Barathi S, Oves M, et al. 2017. Characterization of multifarious plant growth promoting traits of rhizobacterial strain AR6 under Chromium (VI) stress. Microbiol. Res. 204: 65-71. 
116. Zainab N, Bashir Ud Din A, Muhammad Tariq Javed M, Siddique Afridi M, Tehmeena Mukhtar, Kamran Muhammad Aqeel, et al. 2020. Deciphering metal toxicity responses of flax (Linum usitatissimum L.) with exopolysaccharide and ACC-deaminase producing bacteria in industrially contaminated soils. Plant Physiol. Biochem. 152: 90-99.

117. Jittawuttipoka T, Planchon M, Spalla O, Benzerara K, Guyot F, Cassier-Chauvat C, et al. 2013. Multidisciplinary evidences that synechocystis PCC6803 exopolysaccharides operate in cell sedimentation and protection against salt and metal stresses. PLoS One 8: e55564

118. Kalita D, Joshi SR. 2017. Study on bioremediation of Lead by exopolysaccharide producing metallophilic bacterium isolated from extreme habitat. Biotechnol. Rep. 16: 48-57.

119. Getahun A, Muleta D, Assefa F, Kiros S. 2020. Plant growth-promoting rhizobacteria isolated from degraded habitat enhance drought tolerance of acacia (Acacia abyssinica Hochst. ex Benth.) seedlings. Int. J. Microbiol. 2020: 8897998.

120. Mukherjee P, Mitra A, Roy M. 2019. Halomonas Rhizobacteria of Avicennia marina of indian sundarbans promote rice growth under saline and heavy metal stresses through exopolysaccharide production. Front. Microbiol. 10: 1207.

121. Ali J, Ali F, Ahmad I, Rafique M, Munis MFH, Hassan SW, et al. 2020. Mechanistic elucidation of germination potential and growth of Sesbania sesban seedlings with Bacillus anthracis PM21 under heavy metals stress: an in vitro study. Ecotoxicol. Environ. Saf. 208: 111769 .

122. Thijs S, Sillen W, Weyens N, Vangronsveld J. 2017. Phytoremediation: 2017. State-of-the-art and a key role for the plant microbiome in future trends and research prospects. Int. J. Phytoremed. 19: 23-38.

123. Mosa KA, Saadoun I, Kumar K, Helmy M, Dhankher OP. 2016. Potential biotechnological strategies for the clean up of heavy metals and metalloids Front. Plant Sci. 7: 303 .

124. Teixeira EI, Fischer G, Velthuizen HV, Walter C, Ewert F. 2013 Global hot spots of heat stress on agricultural crops due to climate change. Agric. Meteorol. 170: 206-215.

125. FAO (2017). Water Scarcity - One of the greatest challenges of our time. Food and Agriculture Organization of the United Nations.

126. Fahad S, Bajwa AA, Nazir U, Anjum SA, Farooq A, Zohaib A, et al. 2017. Crop production under drought and heat stress: plant responses and management options. Front. Plant Sci. 8: 1147.

127. Kumar S, Thakur P, Kaushal N, Malik J. A Gaur P, Nayyar H. 2013. Effect of varying high temperatures during reproductive growth on reproductive function, oxidative stress and seed yield in chickpea genotypes differing in heat sensitivity. Arch. Agronomy Soil Sci. 59: 823-843.

128. Devasirvatham V, Gaur PM, Mallikarjuna N, Tokachichu RN, Trethowan, RM, Tan DK. 2012. Effect of high temperature on the reproductive development of chickpea genotypes under controlled environments. Funct. Plant Biol. 39: 1009-1018.

129. Kaur R, Bains TS, Bindumadhava H, Nayyar H. 2015. Responses of mungbean (Vigna radiata L.) genotypes to heat stress: effects on reproductive biology, leaf function and yield traits. Sci. Hortic. 197: 527-541.

130. Prasad PV V, Djanaguiraman M, Perumal R, Ciampitti IA. 2015. Impact of high temperature stress on floret fertility and individual grain weight of grain sorghum: sensitive stages and thresholds for temperature and duration. Front. Plant Sci. 6: 1-11.

131. Farooq M, Bramley H, Palta JA, Siddique KHM. 2011. Heat stress in wheat during reproductive and grain-filling phases. CRC Crit. Rev. Plant Sci. 30: 491-507.

132. Sita K, Sehgal A, Kumar J, Kumar S, Singh S, Siddique KH, et al. 2017. Identification of high-temperature tolerant lentil (Lens culinaris Medik.) genotypes through leaf and pollen traits. Front. Plant Sci. 8: 1-26.

133. Bramhachari PV, Nagaraju GP, Kariali E. 2018. Current perspectives on rhizobacterial-EPS interactions in alleviation of stress responses: novel strategies for sustainable agricultural productivity. In Role of Rhizospheric Microbes in Soil; Springer: Singapore. 2018: $33-55$

134. Ali SZ, Sandhya V, Grover M., Linga VR, Bandi V. 2011. Effect of inoculation with a thermo-tolerant plant growth promoting Pseudomonas putida strain AKMP7 on growth of wheat (Triticum spp.) under heat stress. J. Plant. Interact. 6: 239-246.

135. Mukhtar T, Rehman S, Smith D, Sultan T, Seleiman M, Alsadon A, et al. 2020. Mitigation of heat stress in Solanum lycopersicum L. by ACC-deaminase and exopolysaccharide. Producing Bacillus cereus: effects on biochemical profiling. Sustainability 12: 2159.

136. Parsell DA, Lindquist S. 1993. The function of heat shock proteins in stress tolerance: degradation and reactivation of damaged proteins. Annu. Rev. Genet. 27: 437-496.

137. Nandal K, Sehrawat AR, Yadav AS, Vashishat RK, Boora KS. 2005. High temperature-induced changes in exopolysaccharides, lipopolysaccharides, and protein profile of heat-resistant mutants of Rhizobium sp. (Cajanus). Microbiol. Res. 160: 367 - 373.

138. Nguyena HT, Razafindralambo H, Blecker C, N'Yapoa C, Thonart P, Delvignea F. 2014. Stochastic exposure to sub-lethal high temperature enhances exopolysaccharides (EPS) excretion and improves Bifidobacterium bifidum cell survival to freeze-drying. Biochem. Eng. J. 88: 85-94.

139. Bensalim, S, Nowak J, Asiedu SK. 1998 A plant growth promoting rhizobacterium and temperature effects on performance of 18 clones of potato. Am. J. Pot. Res. 75: 145-152.

140. Abd El-Daim I A, Bejai S, Fridborg I. Meijer J. 2018. Identifying potential molecular factors involved in Bacillus amyloliquefaciens 5113 mediated abiotic stress tolerance in wheat. Plant Biol. 20: 271-279.

141. Shin DJ, Yoo SJ, Hong JK, Weon HY, Song J, Sang MK. 2019. Effect of Bacillus aryabhattai H26-2 and B. siamensis H30-3 on Growth promotion and alleviation of heat and drought stresses in Chinese cabbage. Plant Pathol. J. 35: 178-187.

142. Ogden AJ, McAleer JM, Kahn ML. 2019. Characterization of the Sinorhizobium meliloti HslUV and ClpXP protease systems in freeliving and symbiotic states. J. Bacteriol. 201: e00498-18.

143. Nishihata S, Kondo T, Tanaka K. et al. 2018. Bradyrhizobium diazoefficiens USDA110 PhaR functions for pleiotropic regulation of cellular processes besides PHB accumulation. BMC Microbiol. 18: 156

144. Mishra PK, Bisht SC, Ruwari P, Selvakumar G, Joshi GK, Bisht JK, et al. 2018. Alleviation of cold stress in inoculated wheat (Triticum aestivum L.) seedlings with psychrotolerant Pseudomonads from NW Himalayas. Arch Microbiol. 193: 497-513.

145. Zubair M, Hanif A, Farzand A, Sheikh T, Khan A R, Suleman M, et al. 2019. Genetic screening and expression analysis of psychrophilic Bacillus spp. reveal their potential to alleviate cold stress and modulate phytohormones in wheat. Microorganisms 7: 337.

146. Ait Barka E, Nowak J, Clément C. 2006. Enhancement of chilling resistance of inoculated grapevine plantlets with a plant growth promoting Rhizobacterium, Burkholderia phytofirmans strain PsJN. Appl. Environ. Microbiol. 72: 7246-7252.

147. Fernandez O, Theocharis A, Bordiec S, Feil R, Jacquens L, Clément C, et al. 2012. Burkholderia phytofirmans PsJN acclimates grapevine to cold by modulating carbohydrate metabolism. Mol. Plant Microbe Interact. 25: 496-504.

148. Wang C, Wang C, Gao YL, Wang Y-P, Guo J-H. 2016. A Consortium of three plant growth-promoting Rhizobacterium strains acclimates Lycopersicon esculentum and confers a better tolerance to chilling stress. J. Plant Growth Regul. 35: 54-64.

149. Abd El-Daim IA, Bejai S, Meijer J. 2019. Bacillus velezensis 5113 Induced metabolic and molecular reprogramming during abiotic stress tolerance in wheat. Sci. Rep. 9: 16282. 